\title{
Viability of bacteria from different aquatic habitats. I. Environmental conditions and productivity
}

\author{
Rhena Schumann*, Thorsten Rieling, Solvig Görs, Astrid Hammer, Uwe Selig, \\ Ulrich Schiewer
}

University of Rostock, Department of Life Sciences, Institute of Aquatic Ecology, A. Einstein Str. 3, 18059 Rostock, Germany

\begin{abstract}
Various freshwater, estuarine and coastal stations of the Southern Baltic Sea were comparatively studied to evaluate pelagic bacterial performance. Inner coastal waters (so-called bodden or lagoons) are highly productive systems and dominate the coast of the Southern Baltic Sea. Due to high nutrient loads up to the 1990s in combination with an enhanced primary production, increased amounts of particulate (POC) and dissolved organic carbon (DOC) accumulated in these waters. In the Darß-Zingst bodden chain, POC $<16$ and DOC $<13 \mathrm{mg} \mathrm{Cl}^{-1}$, and C:N ratios of 9 to 11 in particulate matter were measured in winter and spring samples. Due to high POC concentrations, the average ratio of DOC:POC was 1.1:1, which is very low compared to other aquatic systems. Bacterial abundance and activities were rather high and reached $24 \times 10^{6} \mathrm{ml}^{-1}$ and $18 \mu \mathrm{g} \mathrm{Cl}^{-1} \mathrm{~h}^{-1}$, respectively. Although 2 of the 3 investigated freshwater systems were classified as eutrophic, the highest measured POC concentrations, bacterial abundance and production were much lower $\left(1.6 \mathrm{mg} \mathrm{Cl}^{-1}, 11 \times\right.$ $10^{6}$ bacteria $\mathrm{ml}^{-1}, 4.4 \mathrm{\mu g} \mathrm{C} \mathrm{l}^{-1} \mathrm{~h}^{-1}$ ) than in the bodden. In contrast to that, the DOC load was as high as in these inner coastal waters $\left(<12 \mathrm{mg} \mathrm{C}^{-1}\right)$. The coastal stations of the Baltic Sea, classified as mesotrophic, were not severely loaded with organic matter and bacteria ( $\mathrm{POC}<0.8, \mathrm{DOC}<5.5 \mathrm{mg} \mathrm{C}$ $\mathrm{l}^{-1}$, bacteria $<3 \times 10^{6} \mathrm{ml}^{-1}$ ). Bacterial production again was lower than at all other stations; however, levels did reach an exceptional $4.6 \mu \mathrm{g} \mathrm{C} \mathrm{l}^{-1} \mathrm{~h}^{-1}$, which is comparable to values of the freshwater systems. Compared to the other investigated marine and freshwater systems, the bodden were heavily loaded with organic matter, especially particulate organic matter (POM). The origin of this material is assumed to be mainly autochthonous as it is known not to be transported by rivers into these estuaries. Although dissolved inorganic nitrogen (DIN) concentrations were high at least in winter, POM was of poor quality; this was reflected by high C:N ratios and a low contribution of phytoplankton carbon to POC. However, this is particularly surprising, because nitrogen should be readily available at all bodden sites by resuspension from the sediment caused by frequent winds in these very shallow systems of $<2 \mathrm{~m}$ depth.
\end{abstract}

KEY WORDS: Organic matter - Bacterial production - Hydrolytic enzymes - Marine systems · Brackish systems $\cdot$ Freshwater systems

Resale or republication not permitted without written consent of the publisher

\section{INTRODUCTION}

Bacteria are the most important decomposers of organic matter in the pelagial and especially in the sediments of aquatic systems (e.g. Chróst et al. 1986). Hydrolytic enzymes, produced mainly by bacteria, play a key role in the degradation of particulate (POM) and dissolved organic matter (DOM) (e.g. Münster et al. 1992). These enzymes are a prerequisite in the transformation of dissolved or colloidal polymeric material to oligo- and monomers, which can then be taken up and metabolised. Therefore, it is useful to compare rates of bacterial production, respiration and hydrolytic enzyme activity in various aquatic systems. Comparisons between bacterial activities and concentrations of organic matter along with dissolved inorganic nitrogen (DIN) and phosphorus in different systems should help to elucidate the coupling of 
organic matter input and decomposition, and subsequently reveal the most important regulating factors of bacterial activity.

Besides nutrient availability, grazing as a top down control factor regulates bacterial biomass and species composition (e.g. Berninger et al. 1991). Protozoa, especially heterotrophic nanoflagellates, are an important, or often the dominating, loss factor for bacterial standing stock in pelagic systems (e.g. Jürgens et al. 1997). Because protozoan grazing pressure influences bacterial standing stock and may modulate bacterial cell specific activity, data on the main grazers are also important to understand organic matter transformations. Other important regulating factors of bacterial biomass and production can be cell lysis by viruses and photoinhibition by ultraviolet radiation (Wilhelm \& Smith 2000).

In this study, different waters were investigated with respect to their organic matter loading, inorganic nutrient status, bacterial biomass and bacterial and protozoan activity. Three freshwater stations, which were classified as meso- to eutrophic, 4 mesotrophic coastal Baltic Sea stations and 5 estuarine locations, ranked between eu- and hypertropic, were compared. The inner coastal waters of the Southern Baltic Sea coast are phytoplankton-dominated systems due to high nutrient influx up to the 1990s. High primary production rates (Wasmund \& Kell 1991) led to enhanced microbial biomasses, including bacteria, phytoplankton, proto- and metazoa. Due to the intensive primary production and the microbial turnover of organic matter, high concentrations of POM and DOM with low nitrogen contents accumulated in these waters (Schumann et al. 2001). In contrast to many other aquatic systems, the POM in the semi-enclosed DarßZingst bodden (lagoon) cannot be washed out substantially into the Baltic Sea due to hydrodynamic and geomorphological factors. In contrast, POM from the river Oberwarnow and its estuary Unterwarnow and from the outer coastal stations is easily transported to the open sea, or in the case of the stratified lake Tiefer See is deposited permanently. Moreover, POM in the bodden is frequently resuspended by wind-induced mixing (Rieling et al. 2000), and processed photochemically and by aerobic micro-organisms. The high C:N ratio in POM and the high percentages of non-carbohydrate and non-proteinaceous material (cf. Schumann et al. 2001) may be the result of these processes and the permanent contribution of sediment material to pelagic seston.

Samples were taken once in winter (January/ February), when high concentrations of DIN were present in all the eutrophicated systems, and once in spring (April/May) at higher water temperatures and lower DIN concentrations. Thus, the growth limiting factor in winter can be assumed to be temperature. This 'limited' situation is compared to the beginning of the phytoplankton spring bloom, where inorganic nutrients for primary production were still 'unlimited' and readily usable organic substances from phytoplankton exudates were already abundant (Schumann 1994).

The aims of this study were: (1) to describe the special environmental conditions of semi-enclosed and extremely shallow estuaries — the bodden-compared to freshwater systems and locations at the outer coast of the Baltic Sea; (2) to relate their effects on organic matter quality and quantity as well as micro-organisms in the pelagial; and (3) to give the data a basis for investigations on bacterial viability and its possible dependence on environmental factors (cf. Schumann et al. 2003, this issue). The following questions are addressed: Does a high organic load result in a high bacterial standing stock as a bottom-up control? Is the high bacterial biomass controlled effectively by protozoa as top-down regulation? Why are the bacteria very active (hydrolytic enzyme activity) but not productive (thymidine and leucine uptake)?

The selected locations provide a broad range of environmental factors. They are situated in an important industrialised region in central Europe and were, until the early 1990s, heavily polluted by fertilisers, pesticides and agricultural wastes. The rivers transported certain other pollutants introduced by the industry, e.g. heavy metals, into the Baltic Sea. However, in the last years, serious action has been taken against this pollution. Phosphorus, pesticide and heavy metal input have been considerably reduced. Additionally, all investigated aquatic systems here are situated in a region primarily used for tourism but also for sustainable and environmentally friendly agriculture. The coastal Baltic Sea stations are in actual fact bathing beaches, and the bodden belong to the Vorpommersche Boddenlandschaft national park. The river Oberwarnow provides drinking water for the town of Rostock.

Although these systems have been investigated for several decades, there are only few data sets published and discussed in scientific journals, especially on micro-organism activity, and most results constitute summarised data given in non-public reports. Hence, it is crucial to evaluate the data from the time of increasing eutrophication and pollution and to follow the process of restoration of these different aquatic systems. The results concerning microbial activities in biogeochemical cycling of organic matter will help (1) to estimate the ecosystem's potential for self-purification; (2) to plan measures for their rehabilitation; and (3) to suggest possibilities for new sustainable industry and agriculture. 


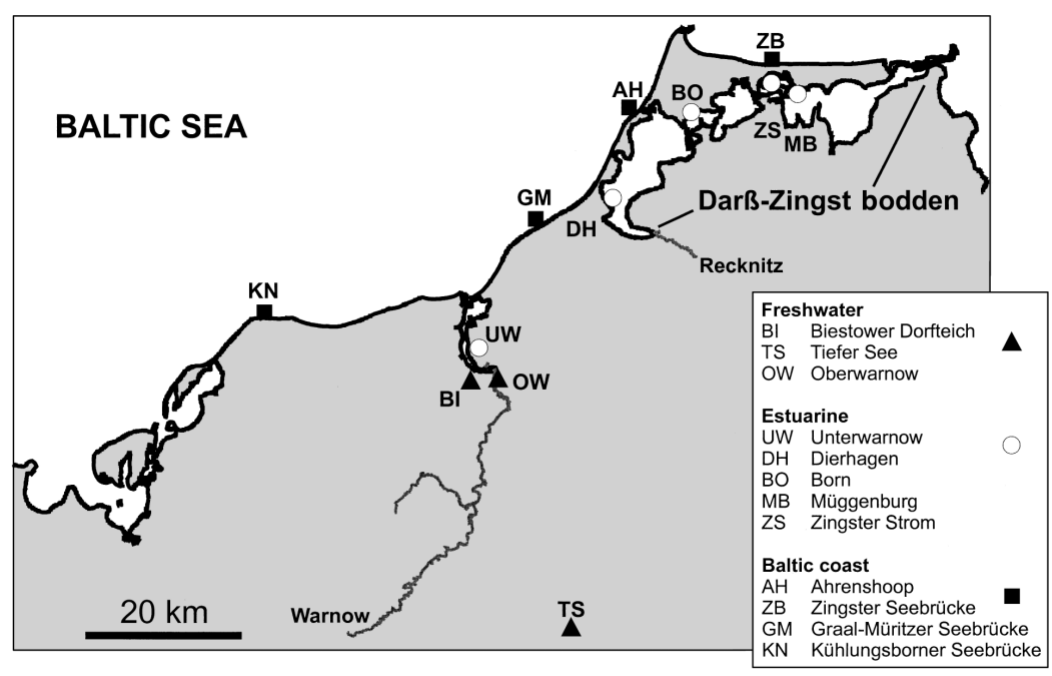

Fig. 1. Investigation area of the southern Baltic Sea coast ( $\boldsymbol{\square})$, the estuarine stations (O) and the sampled freshwater systems $(\mathbf{\Lambda})$

man GF/F). After drying the filters overnight at $60^{\circ} \mathrm{C}$, they were weighed again on an electronic microbalance (M2P, Sartorius). Standard errors of 3 replicates were rather high (1 to $35 \%$ ) due to sediment particles, which occurred at some very shallow stations under stormy conditions in winter. For the quantification of total organic carbon (TOC), unfiltered subsamples were analysed with a total organic carbon analyser (TOC 5000 A, Shimadzu) equipped with a suspended particle kit after catalytic high temperature oxidation (Sugimura \& Suzuki 1988). The corresponding filtrate through precombusted GF/F filters was measured for dissolved organic carbon (DOC). Both results were corrected for inorganic carbon (IC). Particulate organic carbon (POC) was calculated as the difference between TOC and DOC. Organic carbon was

\section{MATERIALS AND METHODS}

Sampling. Different pelagic systems including 3 freshwater, 5 estuarine and 4 coastal stations of the Southern Baltic Sea (Fig. 1) were sampled once in winter at water temperatures below $5^{\circ} \mathrm{C}$ and once during spring at temperatures between 6 and $17^{\circ} \mathrm{C}$ (Table 1). From the upper $50 \mathrm{~cm}, 10 \mathrm{l}$ samples were taken and transported in a cold box to the laboratory within $1 \mathrm{~h}$. They were incubated for activity measurements and processed immediately for all other determinations. Samples were kept at in situ temperature for all viability staining procedures, which were performed within the next $5 \mathrm{~h}$.

Abiotic parameters. Salinity was determined with a LF 197 electrode and expressed as psu (wtw, Wissenschaftlich-technische Werkstätten $\mathrm{GmbH})$. Ammonium, nitrate and nitrite were each estimated spectrophotometrically in Whatman GF/F filtrates after the methods described in Rohde \& Nehring (1979) and summed to DIN. Soluble reactive phosphorus (SRP) was analysed in GF/F filtrates by applying the molybdenum blue method in a flow-through system (Malcolm-Lawes \& Wong 1990).

Seston and organic matter. The amount of suspended particulate matter (seston) was measured by filtering 20 to $400 \mathrm{ml}$ water onto precombusted $\left(450^{\circ} \mathrm{C}\right.$ for $\left.4 \mathrm{~h}\right)$ and pre-weighed glassfibre filters $(25 \mathrm{~mm}$ in diameter, What-
Table 1. Sampling dates in 2000 of the 3 freshwater, 5 estuarine and 4 Baltic Sea coast stations (see Fig. 1 for station abbreviations). $T_{\mathrm{W}}$ : water temperature $\left({ }^{\circ} \mathrm{C}\right)$; Secchi: Secchi depth $(\mathrm{cm})$; SRP: soluble reactive phosphorus $\left(\mu \mathrm{mol} \mathrm{l^{-1 }}\right)$; nd: not determined because too shallow to measure Secchi depth

\begin{tabular}{|c|c|c|c|c|c|c|c|c|}
\hline \multirow[t]{2}{*}{ Stn } & \multicolumn{4}{|c|}{ Winter samples } & \multicolumn{4}{|c|}{ Spring samples } \\
\hline & Date & $T_{\mathrm{W}}$ & Secchi & SRP & Date & $T_{\mathrm{W}}$ & Secchi & SRP \\
\hline \multicolumn{9}{|c|}{ Freshwater } \\
\hline BI & 03 Feb & 4.0 & nd & 32.2 & 04 May & 15.0 & nd & 22.5 \\
\hline TS & 15 Feb & 3.3 & 190 & 0.1 & $18 \mathrm{Apr}$ & 8.5 & 220 & 0.5 \\
\hline OW & 18 Jan & 2.9 & 70 & 1.0 & 07 Apr & 8.0 & 60 & 0.2 \\
\hline \multicolumn{9}{|c|}{ Estuaries } \\
\hline UW & 25 Jan & 0.0 & 105 & 0.9 & 28 Apr & 12.5 & 115 & 0.5 \\
\hline $\mathrm{DH}$ & 17 Feb & 1.5 & 27 & 0.1 & 27 Apr & 12.0 & 25 & 0.4 \\
\hline $\mathrm{BO}$ & 12 Jan & 2.0 & 40 & 0.1 & 19 Apr & 9.5 & 25 & 0.3 \\
\hline MB & 01 Feb & 4.0 & 30 & 0.1 & 17 Apr & 8.0 & 45 & 0.1 \\
\hline $\mathrm{ZS}$ & $24 \mathrm{Feb}$ & 1.0 & 30 & 0.1 & 02 May & 17.4 & 20 & 0.5 \\
\hline \multicolumn{9}{|c|}{ Baltic Sea coast } \\
\hline $\mathrm{AH}$ & 27 Jan & 3.0 & nd & 0.5 & 12 Apr & 5.5 & nd & 0.4 \\
\hline ZB & 22 Feb & 0.5 & 450 & 0.5 & 10 Apr & 6.0 & 450 & 0.3 \\
\hline GM & $10 \mathrm{Feb}$ & 4.0 & nd & 0.7 & $05 \mathrm{Apr}$ & 5.5 & nd & 0.1 \\
\hline $\mathrm{KN}$ & 08 Feb & 5.0 & 120 & 0.4 & 03 Apr & 5.5 & 200 & 0.1 \\
\hline
\end{tabular}


samples of 0.5 to $2.0 \mathrm{ml}$ were filtered onto black stained $0.2 \mu \mathrm{m}$ Isopore ${ }^{\mathrm{TM}}$ polycarbonate filters (Sigma-Aldrich) and stained separately ( $1 \mathrm{mg}$ DAPI in $100 \mathrm{ml}$ phosphate buffer, $\mathrm{pH}$ 7.6, $29 \mu \mathrm{M}$ final concentration) for $10 \mathrm{~min}$. An Olympus BH2-RFCA was used (1250-fold magnification, filter set UG-1). Biovolume was calculated with an individual cell volume of $0.15 \mu^{3}$ (unpubl. data).

Protozoa $>10 \mu \mathrm{m}$ were counted in rafter chambers containing 0.5 to $1.0 \mathrm{ml}$ of water sample in duplicates using a light microscope (BH-2, Olympus) at a magnification of 50-fold. Smaller protozoa (6-fold per sample) were counted in a Bürker blood counting chamber at a magnification of $125 \times$. All animals were counted alive at the day of sampling (Dale \& Burkill 1982) and kept at in situ temperature until examination. Pigment absence was checked by epifluorescence illumination applying green light (BP 545) and a higher magnification if necessary. Biovolume was calculated from measured diameters assuming geometrically objects, e.g. spheres, spheroids or cylinders.

Chlorophyll a (chl a) was extracted with $90 \%$ acetone and measured spectrophotometrically (Jeffrey \& Humphrey 1975).

Bacterial production and community respiration. Bacterial production was measured by the incorporation of ${ }^{3} \mathrm{H}$-thymidine according to Fuhrman \& Azam (1982). Methyl- ${ }^{3} \mathrm{H}$-thymidine $\left(185 \mathrm{GBq} \mathrm{mmol}^{-1}\right.$, Amersham) was added to $3 \mathrm{ml}$ subsamples to give a final concentration of $60 \mathrm{nM}$ and samples were incubated for $30 \mathrm{~min}$ at in situ temperature. Thymidine incorporation was stopped by adding formaldehyde (final concentration $4 \%$ ). Subsequently, nucleic acids of the samples were extracted with $3 \mathrm{ml}$ of $5 \%$ trichloric acid (TCA) and filtered onto $0.2 \mu \mathrm{m}$ cellulose acetate filters. The filters were rinsed 7 -fold with $1 \mathrm{ml}$ of $5 \%$ ice cold TCA. Each filter was then transferred into $10 \mathrm{ml}$ of scintillation cocktail (Ultima Gold, Sigma) and measured in a liquid scintillation counter (Wallac 1410, Pharmacia). Bacterial production was calculated using a thymidine conversion factor of $1.1 \times 10^{18} \mathrm{cells} \mathrm{mol}^{-1}$ (Riemann et al. 1987) and a carbon conversion factor for eutrophic waters of $2.5 \times 10^{-14} \mathrm{~g} \mathrm{C}$ cell $^{-1}$ (Bell 1993).

Bacterial production was additionally measured following the ${ }^{3} \mathrm{H}$-leucine incorporation $(1 \mathrm{nM})$ into bacterial protein, which is insoluble in TCA (Kirchman et al. 1985). To estimate total leucine uptake by the bacterial community, in situ concentrations of leucine were measured by high pressure liquid chromatography after derivatisation with o-phthaldialdehyde (Lindroth \& Mopper 1979, modified according to Hubberten 1994) and related to the turnover rates of the radioactively labelled leucine pool. Total leucine incorporation was converted into biomass production according to Simon \& Azam (1989) assuming a fraction of $7.3 \%$ leucine in bacterial protein and a cellular carbon per protein ratio of 0.86 . Intracellular isotope dilution of leucine by de novo synthesis was assumed to be 2 . We measured 5 replicates per sample with a SE of $29 \%$ on average. The measured low leucine uptake rates, especially at winter in situ temperatures, were the reason for this poor reproducibility.

To measure photosynthesis (data not shown) and community respiration the samples were concentrated by 4 - to 90 -fold by centrifugation $(5000 \mathrm{rpm}, 4500 \times \mathrm{g}$ ) and were kept in the dark at in situ temperature for at least $30 \mathrm{~min}$. An $8 \mathrm{ml}$ aliquot was transferred into the measuring cuvette (Illuminova). Oxygen concentration was measured by a Clark-type electrode MI-730 (response time $<20 \mathrm{~s}$, Microelectrodes), inserted at the back of the cuvette. Prior to each measurement, the system was calibrated against air-saturated seawater at experimental temperature $(=100 \%$ oxygen saturation) and against an oxygen-free sodium dithionite solution ( $=0 \%$ oxygen). The oxygen concentrations in the concentrated samples were followed for $10 \mathrm{~min}$ in darkness to determine the respiration rate. At the beginning of the respiration measurements, the initial oxygen saturation was $>80 \%$ in most samples. All measured data (oxygen concentration and changes with time, temperature, velocity of the stirrer) were recorded every $4 \mathrm{~s}$. Respiration was calculated as the slope of the linear regression of the oxygen decline with time. A respiratory quotient of 0.88 was applied for the conversion into carbon (Robinson et al. 1999).

Hydrolytic enzyme activity. Total esterase and peptidase activities were measured as the enzymatical hydrolysis of 4-methylumbelliferyl butyrate (MUFbutyrate) and L-leucine-4-methyl-7-coumarinylamide hydrochloride (Leu-MCA) (Sigma-Aldrich), respectively. The procedure followed Hoppe (1983), with minor adaptations. The artificial substrates were dissolved in $100 \%$ ethanol and added to $2 \mathrm{ml}$ subsamples at a final concentration of $91 \mu \mathrm{M}$. All samples were buffered at a $\mathrm{pH}$ of 8.2 with Tris buffer $(1 \mathrm{ml} 50 \mathrm{mM}$ Tris/HCl per $10 \mathrm{ml}$ sample). Three replicates per sample were incubated at room temperature $\left(21^{\circ} \mathrm{C}\right)$ and recorded for the fluorescent hydrolysis product 3 fold within $2 \mathrm{~h}$ for esterase and 3 to $9 \mathrm{~h}$ for peptidase activities in a Hitachi F4010 fluorometer (excitation $365 \mathrm{~nm}$, emission $451 \mathrm{~nm}$, bandpass $1.5 \mathrm{~nm}$, response $2 \mathrm{~s}$, averaged over $2 \mathrm{~s}$ ). Blanks of sterile-filtered, distilled water and the fluorogenic substrates were treated the same way to correct the results for nonenzymatic hydrolysis, which could be substantial for the MUF-butyrate at the chosen $\mathrm{pH}$ of 8.2. The linear increase of fluorescence over time represents the hydrolytic enzyme activity. Standards of 1 to $100 \mu \mathrm{M} 4$ MUF (=7-hydroxy-4-methylcoumarin) and 7-amino-4methylcoumarin (AMC) in $50 \mathrm{nM}$ Tris-buffer, $\mathrm{pH} 8.2$ were measured at each sampling date to calibrate 
hydrolysis rates from relative fluorescence units. The same procedure was carried out with filtrates through $0.2 \mu \mathrm{m}$ cellulose acetate membranes of each sample to quantify the amount of free dissolved enzyme activity.

Statistical analysis. To prove associations between abiotic factors, organic material, micro-organisms and their activities a Spearman rank order correlation analysis was performed on the whole data set. A critical p-value of $<0.05$ was always applied. Differences between average concentrations found at the freshwater, the Darß-Zingst bodden and the Baltic Sea stations were detected by 1-way ANOVA if the data passed normality test. In that case, average concentrations are the arithmetic means. However, the majority of data was not distributed normally and therefore variances were analysed by Kruskal-Wallis 1-way analysis on ranks. Hence, the medians serve as average values. A critical $p$-value of $<0.05$ was always applied. The all pairwise multiple comparison Dunn's method was used to isolate the significantly differing values.

\section{RESULTS}

\section{Environmental conditions}

The 3 freshwater systems (Fig. 1) include very different water types: the shallow and slow running eutrophic river Warnow (with sampling location Oberwarnow, OW: cf. Schumann et al. 1992, Hübener et al. 1996, Schlungbaum \& Selig 1996), a small, shallow village pond (BI), and the $31 \mathrm{~m}$ deep dimictic meso- to eutrophic lake Tiefer See (TS: cf. Gewässergütebericht Mecklenburg-Vorpommern 1996/1997). The estuarine stations (UW and the 4 Darß-Zingst bodden stations $\mathrm{DH}, \mathrm{BO}, \mathrm{MB}$ and $\mathrm{ZS}$ ) are more similar concerning morphological data, especially since 4 of the 5 are situated very close together in the same inner coastal water system. However, they are quite different regarding their eutrophication status (Schmidt 1989, Schiewer et al. 1991, Wasmund \& Kell 1991). The Unterwarnow estuary is the least eutrophicated estuary, because of its intensive water exchange with the Baltic Sea. The DarßZingst bodden stations are hypertrophic in the inner western parts, because the water exchange with the Baltic is very restricted there, and eutrophic in the east. The outer coastal stations of the Baltic Sea (AH, ZB, GM and KN) are mesotrophic (Wasmund et al. 2000). Maximum water depth at the sampling points was about $5 \mathrm{~m}$. Secchi depths of the mesotrophic stations were greater than $120 \mathrm{~cm}$ (Table 1). The eutrophic inner coastal stations had very low Secchi depths of only 20 to $45 \mathrm{~cm}$.

In the estuarine systems, i.e. the inner coastal stations, salinity ranged from 1.5 to $7.7 \mathrm{psu}$. In the outer coastal Baltic Sea stations, salinity was significantly higher (9.5 to $17.0 \mathrm{psu}$ ). The sampling stations are lined up in each figure with increasing salinity measured in the winter samples (cf. Fig. 2a).

Of the limnetic systems only the eutrophic river Oberwarnow (OW) had rather high DIN concentrations, predominantly as nitrate. Besides lower water temperatures in winter, only the DIN concentrations dropped clearly between winter and spring, by $16 \%$ in freshwater and by 67 and $62 \%$ in the brackish and Baltic Sea samples, respectively (Fig. 3). All other abiotic parameters did not change significantly between the 2 sampling periods. At all sampling dates, SRP concentrations were very low except in the village pond (BI; Table 1).

There were significant negative correlations between micro-organisms - measured as bacterial numbers, chl a concentrations and protozoan biomassand salinity. DIN was positively correlated with the micro-organisms and bacterial production, determined via thymidine incorporation (Table 2).
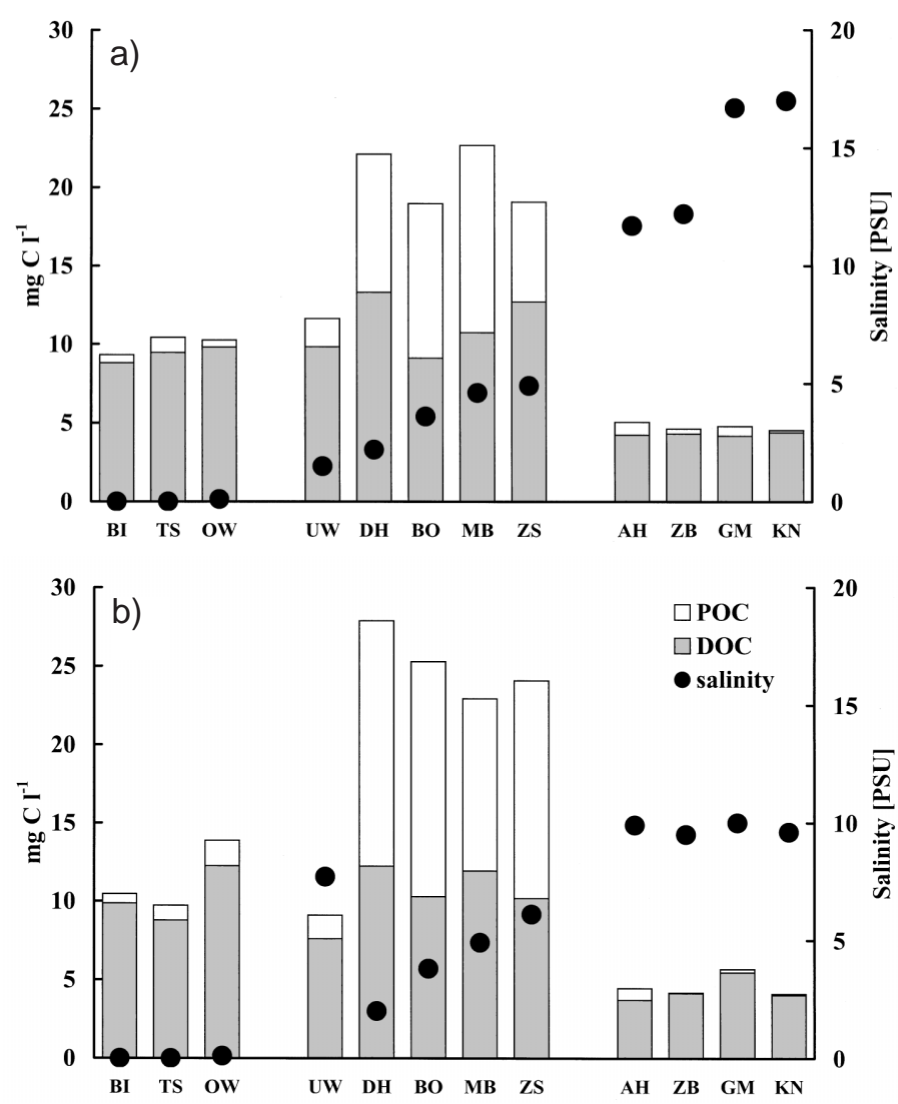

Fig. 2. Dissolved (DOC) and particulate organic carbon (POC) $\left(\mathrm{mg} \mathrm{Cl}^{-1}\right)$ at the freshwater, estuarine and Baltic Sea stations (see Fig. 1 for station abbreviations) lined up by increasing salinity (psu) in (a) winter and (b) spring (see Table 1 for sampling dates) 

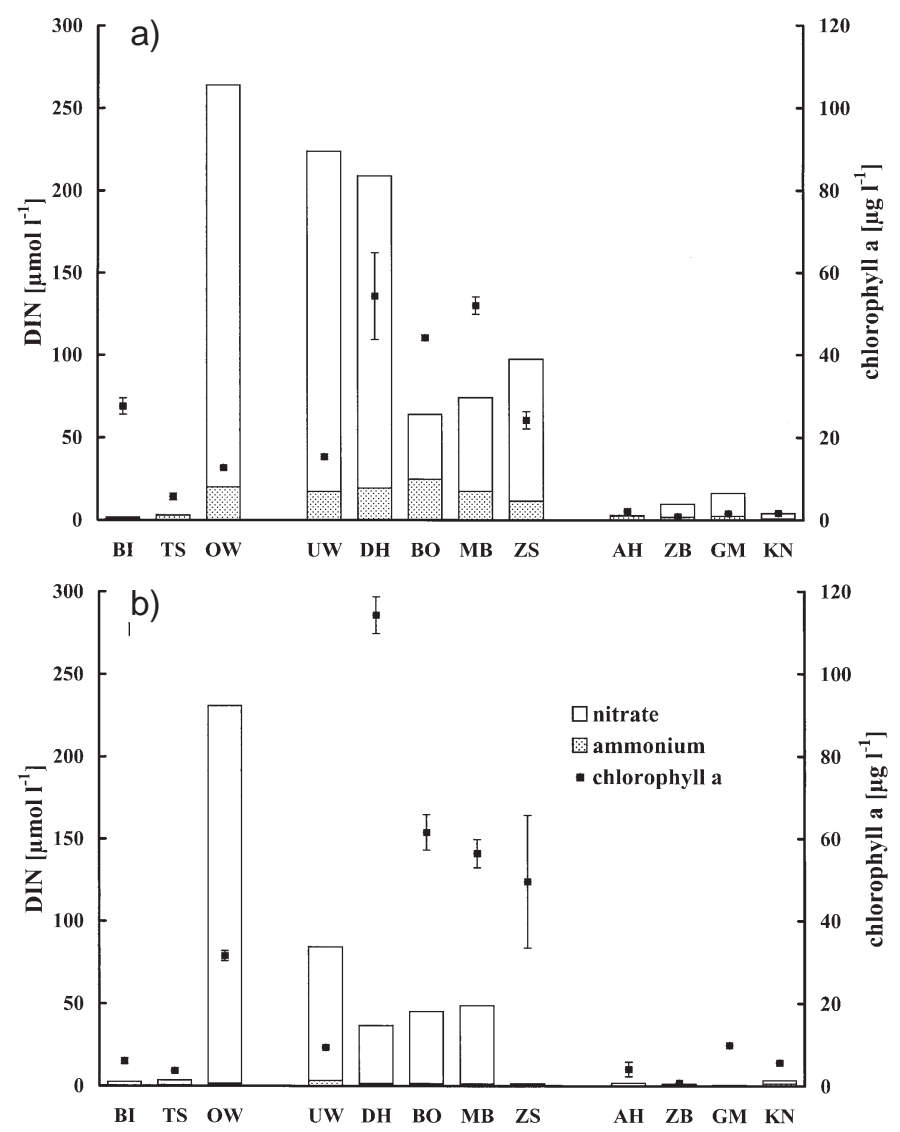

Fig. 3. Dissolved inorganic nitrogen (DIN) $\left(\mu \mathrm{mol}^{-1}\right)$ and chlorophyll a (chl a) concentrations ( $\mu \mathrm{gl}^{-1}$ ) in (a) winter and (b) spring. Stations are arranged as in Fig. 2 (see Fig. 1 for station abbreviations). Error bars of chl a: SD of 3 replicate measurements

\section{Organic material}

DOC concentrations were high at the freshwater and estuarine stations ( 8 to $13 \mathrm{mg} \mathrm{C}^{-1}$ ). The POC concentrations in the freshwater systems were low $\left(<2 \mathrm{mg} \mathrm{C}^{-1}\right)$, so that the ratio between DOC and POC was on average 14:1. The POC contents were 2 to $16 \mathrm{mg} \mathrm{C}^{-1}$ and were highest in the brackish samples, resulting in DOC:POC ratios of only $2: 1$. In the Baltic Sea, DOC and POC amounts were both much lower and the ratio between them was 35:1 on average (Fig. 2).

The $\mathrm{C}: \mathrm{N}$ ratio was lowest in the freshwater systems (7.4 on average) and moderate in the estuarine samples (9.2). The occasional resuspension of mineral sediment material into the pelagial of the rather shallow Baltic Sea stations resulted in high seston amounts (not shown), but not enhanced POC (cf. Fig. 2). The $\mathrm{C}: \mathrm{N}$ ratio of POM was highly variable and reached a maximum of 23.1 (Fig. 4).

While the freshwater stations exhibited chl a concentrations ranging from 4 to $32 \mu \mathrm{g} \mathrm{l}^{-1}$ in spring, all estuarine locations developed up to $114 \mu \mathrm{g} \mathrm{l^{-1 }}$ and the Baltic Sea stations only $10 \mu \mathrm{g}$ chl a $\mathrm{l}^{-1}$ maximum

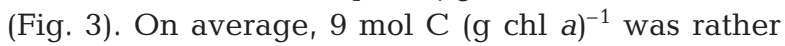
high for the freshwater systems, but average values at the estuarine stations were nearly twice as high $\left(17 \mathrm{~mol} \mathrm{C}\left[\mathrm{g} \mathrm{chl} \mathrm{a}^{-1}\right)\right.$. While 3 out of the 4 Baltic Sea sampling sites showed POC:chl a ratios of $31 \mathrm{~mol} \mathrm{C}$ $(\mathrm{g} \mathrm{chl} a)^{-1}$, the other Baltic Sea site $(\mathrm{KN})$ averaged at $5 \mathrm{~mol} \mathrm{C}(\mathrm{g} \mathrm{chl} \mathrm{a})^{-1}$. These high POC:chl a ratios in the winter samples may have been the result of interfer-

Table 2. Spearman rank order correlation between salinity (psu), water temperture $\left(T_{\mathrm{W}}\right)\left({ }^{\circ} \mathrm{C}\right)$, dissolved inorganic nitrogen (DIN) $\left(\mu \mathrm{mol} \mathrm{l} \mathrm{l}^{-1}\right)$, dissolved organic carbon (DOC) $\left(\mathrm{mg} \mathrm{C}^{-1}\right)$, seston $\left(\mathrm{mg}\right.$ dry $\left.\mathrm{wt} \mathrm{l}^{-1}\right)$, the $\mathrm{C}: \mathrm{N}$ ratio in particulate organic matter $(\mathrm{C}: \mathrm{N}$ in $\mathrm{POM})$ and bacteria $\left(10^{6} \mathrm{ml}^{-1}\right)$, chlorophyll a $(\mathrm{chl} \mathrm{a})\left(\mathrm{g} \mathrm{l}^{-1}\right)$, protozoan biomass $\left(\mathrm{mg} \mathrm{C}^{-1}\right)$, bacterial production measured by thymidine and leucine uptake $\left(\mu \mathrm{g} \mathrm{Cl}^{-1} \mathrm{~d}^{-1}\right)$, community respiration $\left(\mu \mathrm{mol} \mathrm{O} \mathrm{O}^{-1} \mathrm{~h}^{-1}\right)$, esterase and peptidase activity $\left(\mu \mathrm{mol} \mathrm{l}^{-1} \mathrm{~h}^{-1}\right)$. Data from all stations: $\mathrm{n}=24 ; \mathrm{r}_{\mathrm{S}}$ : correlation coefficient; $\mathrm{p}$ : error probability; ${ }^{*}$ : significantly correlated with $\mathrm{p}<0.05$

\begin{tabular}{|c|c|c|c|c|c|c|c|c|}
\hline & & Salinity & $T_{\mathrm{W}}$ & DIN & DOC & Seston & POC & $\mathrm{C}: \mathrm{N}$ in $\mathrm{POM}$ \\
\hline Bacteria & $\begin{array}{c}\mathrm{r}_{\mathrm{S}} \\
\mathrm{p}\end{array}$ & $\begin{array}{c}-0.48^{*} \\
0.02\end{array}$ & $\begin{array}{l}0.12 \\
0.59\end{array}$ & $\begin{array}{l}0.51^{*} \\
0.01\end{array}$ & $\begin{array}{l}0.71^{*} \\
0\end{array}$ & $\begin{array}{l}0.43^{*} \\
0.04\end{array}$ & $\begin{array}{l}0.84^{*} \\
0\end{array}$ & $\begin{array}{l}0.07 \\
0.74\end{array}$ \\
\hline Chl a & $\begin{array}{l}\mathrm{r}_{\mathrm{S}} \\
\mathrm{p}\end{array}$ & $\begin{array}{c}-0.45^{*} \\
0.03\end{array}$ & $\begin{array}{l}0.09 \\
0.68\end{array}$ & $\begin{array}{l}0.43^{*} \\
0.03\end{array}$ & $\begin{array}{l}0.82^{*} \\
0\end{array}$ & $\begin{array}{l}0.53^{*} \\
0.01\end{array}$ & $\begin{array}{l}0.81^{*} \\
0\end{array}$ & $\begin{array}{l}0.21 \\
0.33\end{array}$ \\
\hline Protozoan biomass & $\begin{array}{l}\mathrm{r}_{\mathrm{S}} \\
\mathrm{p}\end{array}$ & $\begin{array}{l}-0.69^{*} \\
0\end{array}$ & $\begin{array}{r}-0.10 \\
0.64\end{array}$ & $\begin{array}{l}0.41^{*} \\
0.04\end{array}$ & $\begin{array}{l}0.70^{*} \\
0\end{array}$ & $\begin{array}{l}0.24 \\
0.26\end{array}$ & $\begin{array}{l}0.62^{*} \\
0\end{array}$ & $\begin{array}{r}-0.03 \\
0.89\end{array}$ \\
\hline Thymidine uptake & $\begin{array}{l}\mathrm{r}_{\mathrm{S}} \\
\mathrm{p}\end{array}$ & $\begin{array}{r}-0.27 \\
0.21\end{array}$ & $\begin{array}{r}-0.36 \\
0.09\end{array}$ & $\begin{array}{l}0.48^{*} \\
0.02\end{array}$ & $\begin{array}{l}0.71^{*} \\
0\end{array}$ & $\begin{array}{l}0.46^{*} \\
0.03\end{array}$ & $\begin{array}{l}0.72^{*} \\
0\end{array}$ & $\begin{array}{l}0.31 \\
0.14\end{array}$ \\
\hline Leucine uptake & $\begin{array}{l}\mathrm{r}_{\mathrm{S}} \\
\mathrm{p}\end{array}$ & $\begin{array}{r}-0.11 \\
0.60\end{array}$ & $\begin{array}{l}0.18 \\
0.42\end{array}$ & $\begin{array}{l}0.24 \\
0.26\end{array}$ & $\begin{array}{l}0.45^{*} \\
0.03\end{array}$ & $\begin{array}{l}0.61^{*} \\
0\end{array}$ & $\begin{array}{l}0.59^{*} \\
0\end{array}$ & $\begin{array}{l}0.38 \\
0.06\end{array}$ \\
\hline Respiration & $\begin{array}{l}\mathrm{r}_{\mathrm{S}} \\
\mathrm{p}\end{array}$ & $\begin{array}{r}-0.08 \\
0.73\end{array}$ & $\begin{array}{r}-0.22 \\
0.34\end{array}$ & $\begin{array}{l}0.36 \\
0.10\end{array}$ & $\begin{array}{l}0.58^{*} \\
0.01\end{array}$ & $\begin{array}{l}0.70^{*} \\
0\end{array}$ & $\begin{array}{l}0.71^{*} \\
0\end{array}$ & $\begin{array}{l}0.42 \\
0.05\end{array}$ \\
\hline Esterase & $\begin{array}{l}\mathrm{r}_{\mathrm{S}} \\
\mathrm{p}\end{array}$ & $\begin{array}{r}-0.37 \\
0.07\end{array}$ & $\begin{array}{l}0.29 \\
0.18\end{array}$ & $\begin{array}{l}0.28 \\
0.18\end{array}$ & $\begin{array}{l}0.77^{*} \\
0\end{array}$ & $\begin{array}{l}0.64^{*} \\
0\end{array}$ & $\begin{array}{l}0.85^{*} \\
0\end{array}$ & $\begin{array}{l}0.17 \\
0.43\end{array}$ \\
\hline Peptidase & $\begin{array}{l}\mathrm{r}_{\mathrm{S}} \\
\mathrm{p}\end{array}$ & $\begin{array}{c}-0.54^{*} \\
0.01\end{array}$ & $\begin{array}{l}0.28 \\
0.19\end{array}$ & $\begin{array}{l}0.30 \\
0.15\end{array}$ & $\begin{array}{l}0.84^{*} \\
0\end{array}$ & $\begin{array}{l}0.53^{*} \\
0.01\end{array}$ & $\begin{array}{l}0.85^{*} \\
0\end{array}$ & $\begin{array}{l}0.13 \\
0.55\end{array}$ \\
\hline
\end{tabular}



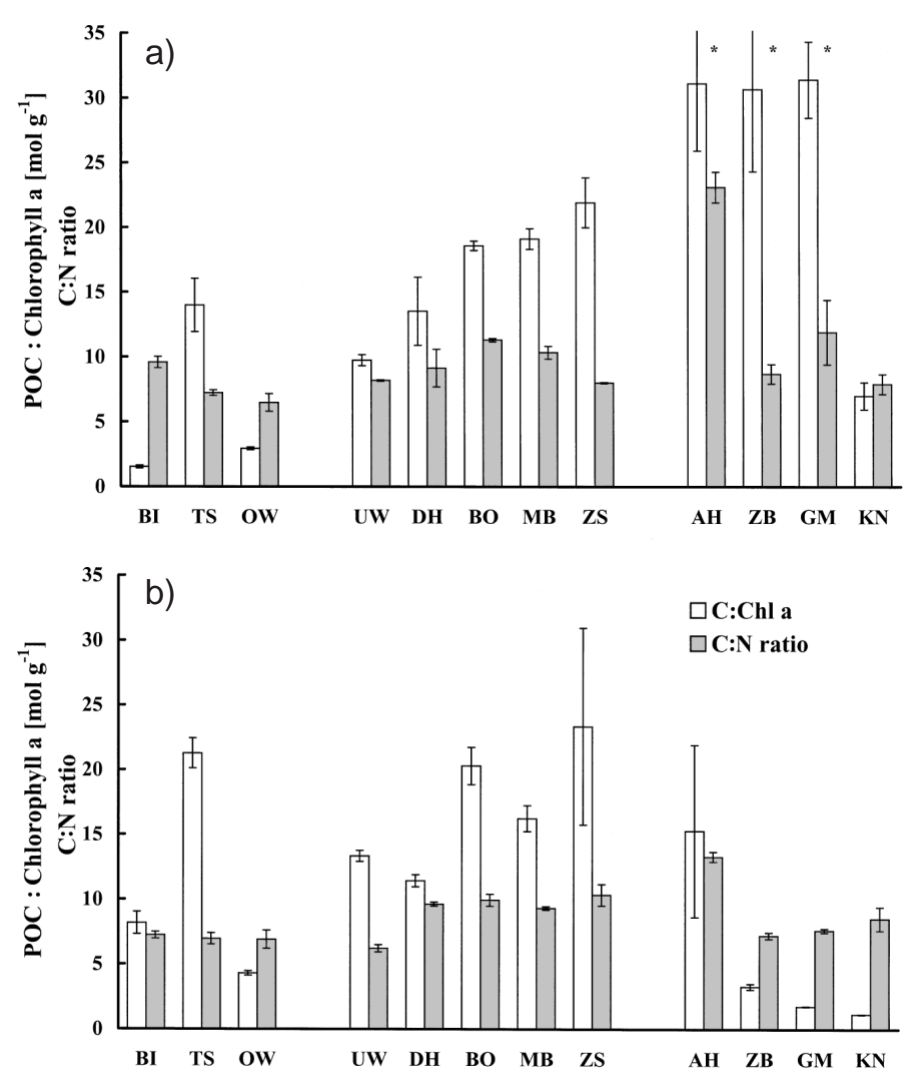

Fig. 4. POC:chlorophyll a $(\mathrm{chl} \mathrm{a})\left(\mathrm{mol} \mathrm{g}^{-1}\right)$ and $\mathrm{C}: \mathrm{N}$ ratios of particulate matter (mol:mol) in (a) winter and (b) spring. Stations are arranged as in Fig. 2 (see Fig. 1 for station abbreviations). Error bars: SD of 3 replicate measurements. ${ }^{*}$ Samples with resuspended sediments excluded from statistical analyses

ence with resuspended material, because they were taken during or immediately after storms. The ratios were considerably smaller in spring (Fig. 4).

POC and DOC were strongly correlated with biomass and activities of all micro-organisms. Community respiration, hydrolytic enzyme activities and bacterial production were all also significantly correlated to organic matter quantities. However, there was no correlation to the $\mathrm{C}: \mathrm{N}$ ratio of POM (Table 2).

\section{Heterotrophic organisms}

Bacteria in the freshwater systems reached between 4.4 and $10.9 \times 10^{6}$ cells ml $^{-1}$ and were exceeded 2 -fold by cell numbers in the estuarine samples. In contrast, bacteria in the Baltic Sea samples were 7 -fold lower than in the estuaries. Differences between cell numbers in winter and spring were not significant.

In winter, up to 19 ciliates were counted per ml. Heterotrophic flagellates averaged $782 \mathrm{ml}^{-1}$ in freshwater and $1510 \mathrm{ml}^{-1}$ in estuarine samples. Flagellates were then completely absent in the Baltic Sea. In $3 / 4$ of the samples, protozoan abundance was much higher in spring, with ciliates increasing to 43,60 and $8 \mathrm{ml}^{-1}$ in freshwater, estuaries and the Baltic Sea, respectively. Heterotropic flagellates increased to 2170, 4670 and $360 \mathrm{ml}^{-1}$ in freshwater, estuaries and the Baltic Sea, respectively (Fig. 5).

Bacteria dominated heterotrophic biovolume at $82 \%$ on average at all stations. Ciliates accounted for $12 \%$ of biovolume because of their much higher individual volume in comparison to flagellates. Heterotrophic flagellates, most of them in the 'nano' size class between 2 and $20 \mu \mathrm{m}$ in diameter, reached only $6 \%$ on average and up to $29 \%$ maximum of total heterotrophic biovolume. While differences between stations and seasons were insignificant, bacteria, protozoa and phytoplankton were significantly correlated (Table 3).

\section{Heterotrophic activities}

The limnetic waters were characterised by comparably low bacterial production rates (average $51 \mu \mathrm{g}$ $\mathrm{C}^{-1} \mathrm{~d}^{-1}$ ). At nearly all estuarine stations, the bacterial carbon production was higher than in the other envi-
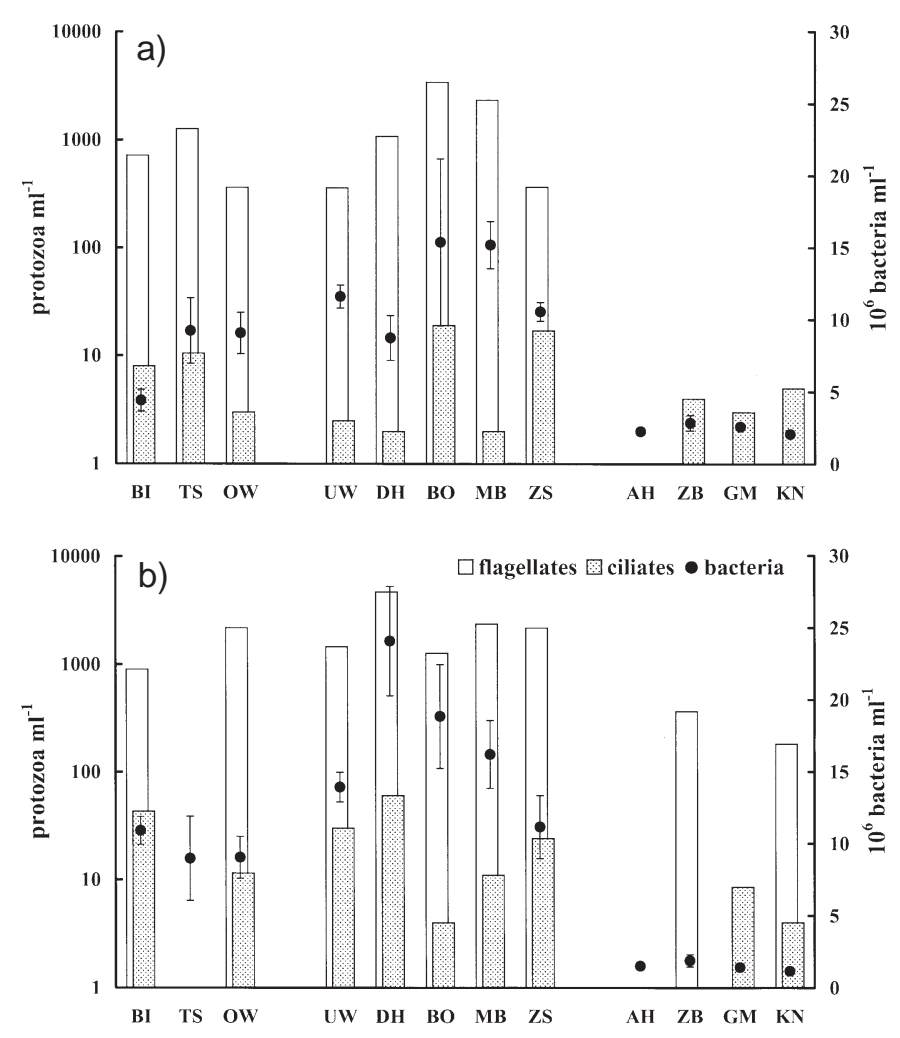

Fig. 5. Abundances of heterotrophic micro-organisms (ind. $\mathrm{ml}^{-1}$ ) in (a) winter and (b) spring. Stations are arranged as in Fig. 2 (see Fig. 1 for station abbreviations). Error bars of bacterial abundance: SD of 4 replicate measurements 
Table 3. Spearman rank order correlation between bacteria $\left(10^{6} \mathrm{ml}^{-1}\right)$, chlorophyll a ( $\mathrm{chl}$ a) $\left(\mathrm{g} \mathrm{g} \mathrm{l}^{-1}\right)$, protozoan biomass $\left(\mathrm{mg} \mathrm{C}^{-1}\right)$ and bacterial production measured by thymidine $(\mathrm{T})$ and leucine $(\mathrm{L})$ uptake $\left(\mu \mathrm{g} \mathrm{C} \mathrm{^{-1 }}\right.$ $\mathrm{d}^{-1}$ ), bacterial productivity calculated as ratios between production and biomass (P:B) on the basis of $\mathrm{T}$ and $\mathrm{L}$ incorporation ( $\mu \mathrm{g} \mathrm{C} \mu \mathrm{g} \mathrm{C}^{-1} \mathrm{~d}^{-1}$ ) community respiration $\left(\mu \mathrm{mol} \mathrm{O} \mathrm{O}_{2} \mathrm{l}^{-1} \mathrm{~h}^{-1}\right)$, esterase and peptidase activity $\left(\mu \mathrm{mol} \mathrm{l} \mathrm{l}^{-1} \mathrm{~h}^{-1}\right)$, cell specific enzyme activities $\left(\mathrm{fmol} \mathrm{l}^{-1} \mathrm{~h}^{-1}\right)$ calculated from bacterial abundances, portions of free-dissolved enzyme activities (\%). Data from all stations: $\mathrm{n}=24 ; \mathrm{r}_{\mathrm{S}}$ : correlation coefficient; $\mathrm{p}$ : error probability; $^{*}$ : significantly correlated with $\mathrm{p}<0.05$

\begin{tabular}{|c|c|c|c|c|}
\hline & & Bacteria & Chl a & $\begin{array}{c}\text { Protozoan } \\
\text { biomass }\end{array}$ \\
\hline Thymidine uptake & $\begin{array}{l}\mathrm{r}_{\mathrm{S}} \\
\mathrm{p}\end{array}$ & $\begin{array}{l}0.65^{*} \\
0\end{array}$ & $\begin{array}{l}0.77^{*} \\
0\end{array}$ & $\begin{array}{l}0.59^{*} \\
0\end{array}$ \\
\hline $\mathrm{P}: \mathrm{B}$ ratio $(\mathrm{T})$ & $\begin{array}{l}\mathrm{r}_{\mathrm{S}} \\
\mathrm{p}\end{array}$ & $\begin{array}{r}-0.12 \\
0.59\end{array}$ & $\begin{array}{l}0.25 \\
0.23\end{array}$ & $\begin{array}{l}0.04 \\
0.84\end{array}$ \\
\hline Leucine uptake & $\begin{array}{l}\mathrm{r}_{\mathrm{S}} \\
\mathrm{p}\end{array}$ & $\begin{array}{l}0.63^{*} \\
0\end{array}$ & $\begin{array}{l}0.62^{*} \\
0\end{array}$ & $\begin{array}{l}0.36 \\
0.08\end{array}$ \\
\hline $\mathrm{P}: \mathrm{B}$ ratio $(\mathrm{L})$ & $\begin{array}{l}\mathrm{r}_{\mathrm{S}} \\
\mathrm{p}\end{array}$ & $\begin{array}{r}-0.23 \\
0.28\end{array}$ & $\begin{array}{r}-0.02 \\
0.91\end{array}$ & $\begin{array}{r}-0.27 \\
0.20\end{array}$ \\
\hline Respiration & $\begin{array}{l}\mathrm{r}_{\mathrm{S}} \\
\mathrm{p}\end{array}$ & $\begin{array}{l}0.77^{*} \\
0\end{array}$ & $\begin{array}{l}0.71^{*} \\
0\end{array}$ & $\begin{array}{l}0.48^{*} \\
0.03\end{array}$ \\
\hline Esterase activity & $\begin{array}{l}\mathrm{r}_{\mathrm{S}} \\
\mathrm{p}\end{array}$ & $\begin{array}{l}0.80^{*} \\
0\end{array}$ & $\begin{array}{l}0.80^{*} \\
0\end{array}$ & $\begin{array}{l}0.65^{*} \\
0\end{array}$ \\
\hline Cell specific esterase & $\begin{array}{c}\mathrm{r}_{\mathrm{S}} \\
\mathrm{p}\end{array}$ & $\begin{array}{l}0.72^{*} \\
0\end{array}$ & $\begin{array}{l}0.69^{*} \\
0\end{array}$ & $\begin{array}{l}0.70^{*} \\
0\end{array}$ \\
\hline Portion of free esterase & $\begin{array}{c}\mathrm{r}_{\mathrm{S}} \\
\mathrm{p}\end{array}$ & $\begin{array}{l}-0.76^{*} \\
0\end{array}$ & $\begin{array}{l}-0.78^{*} \\
0\end{array}$ & $\begin{array}{l}-0.78^{*} \\
0\end{array}$ \\
\hline Peptidase & $\begin{array}{l}\mathrm{r}_{\mathrm{S}} \\
\mathrm{p}\end{array}$ & $\begin{array}{l}0.80^{*} \\
0\end{array}$ & $\begin{array}{l}0.92^{*} \\
0\end{array}$ & $\begin{array}{l}0.68^{*} \\
0\end{array}$ \\
\hline Cell specific peptidase & $\begin{array}{c}\mathrm{r}_{\mathrm{S}} \\
\mathrm{p}\end{array}$ & $\begin{array}{l}0.78^{*} \\
0\end{array}$ & $\begin{array}{l}0.90^{*} \\
0\end{array}$ & $\begin{array}{l}0.74^{*} \\
0\end{array}$ \\
\hline Portion of free peptidase & $\begin{array}{l}\mathrm{r}_{\mathrm{S}} \\
\mathrm{p}\end{array}$ & $\begin{array}{r}-0.35 \\
0.09\end{array}$ & $\begin{array}{r}-0.39 \\
0.06\end{array}$ & $\begin{array}{r}-0.20 \\
0.34\end{array}$ \\
\hline Bacteria & $\begin{array}{c}\mathrm{r}_{\mathrm{S}} \\
\mathrm{p}\end{array}$ & - & $\begin{array}{l}0.73^{*} \\
0\end{array}$ & $\begin{array}{l}0.68^{*} \\
0\end{array}$ \\
\hline Chl a & $\begin{array}{c}\mathrm{r}_{\mathrm{S}} \\
\mathrm{p}\end{array}$ & & - & $\begin{array}{l}0.68^{*} \\
0\end{array}$ \\
\hline
\end{tabular}

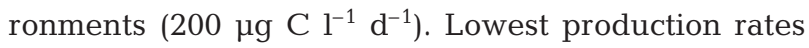
occurred at the Baltic Sea stations $\left(29 \mu \mathrm{C} \mathrm{l}^{-1} \mathrm{~d}^{-1}\right.$; Fig. 6). The productivity, expressed as production per biomass per day (P:B) based on thymidine uptake reached 0.3 for the freshwater bacteria, 0.6 at the estuarine stations and 0.5 in the Baltic Sea. In only 4 samples did bacterial production rates increase at higher water temperatures in spring (Fig. 6). The molar ratio between leucine and thymidine uptake was on average 6 for the freshwater stations, 3 for the estuarine and 4 for the Baltic Sea samples.

The freshwater samples had low community respiration rates (average $130 \mu \mathrm{g} \mathrm{C}^{-1} \mathrm{~d}^{-1}$ ). Respiration was highest in the estuarine samples $\left(913 \mu \mathrm{g} \mathrm{C} \mathrm{l}^{-1} \mathrm{~d}^{-1}\right)$ and lowest in the Baltic Sea $\left(103 \mu \mathrm{g} \mathrm{C}^{-1} \mathrm{~d}^{-1}\right)$. Higher water temperatures in spring did not result in significantly higher respiration rates (Fig. 6).
Esterase and peptidase activities were moderate in the freshwater systems and highest at the estuarine stations. At the Baltic Sea stations, the esterase activity was on average 4 -fold lower than at the estuarine stations, but the peptidase activity was even lower (34-fold) (Fig. 7). In the limnetic and brackish samples, the esterase exceeded the peptidase activity by 3 - to 15 -fold. Because of the very low peptidase activities in the Baltic Sea samples, this ratio ranged from 21- to 91 fold. The portion of free-dissolved esterase was, even at $38 \%$, rather high in fresh and estuarine waters, but much higher at the Baltic Sea stations (79\%). In contrast, freedissolved peptidase was not significant, contributing only up to $8 \%$ of the total activity. At all stations, spring values were on average only 1.5-fold higher for esterase and 2.3-fold higher for peptidase compared to the winter activities.

Bacterial production and hydrolytic enzyme activities increased significantly with bacterial abundance. The bacterial activities were also significantly correlated to phytoplankton and protozoa, but because micro-organism abundance or biomass were also correlated, it is impossible to prove direct interrelationships between bacterial production and phytoplankton or protozoa. Bacterial productivity (P:B ratio) did not change with bacteria or any other biomass parameter (Table 3). In contrast, hydrolytic enzyme activity normalised to bacterial cells was higher in samples with high bacterial abundance. Community respiration was correlated to all micro-organism biomass parameters (Table 3 ).

\section{DISCUSSION}

\section{Darß-Zingst bodden — rich in POM}

Salinity, DOC:POC ratios and the concentrations of each were chosen as the main parameters to group the sampled stations. At the freshwater sites, DOC was as high as at the estuarine bodden locations, but POC was much lower. At the Baltic Sea stations, both POC and DOC were lower than at any other investigated station (cf. Fig. 2). In contrast, the POC concentrations of the limnetic and marine sites were well in the range of values reported for other freshwater or marine systems, respectively. POC in the bodden was rather high in comparison to other estuaries (cf. overview in Schumann et al. 2001). DOC concentrations of the meso- to 
eutrophic freshwater sampling sites were similar to those of other eutrophic lakes. The DOC content in the Darß-Zingst bodden was rather moderate, although they are hypertrophic. There are several large estuaries and hypertrophic or humic lakes with maximum DOC concentrations about twice as high. DOC concentrations in the open ocean peak at about $3 \mathrm{mg} \mathrm{l}^{-1}$. In

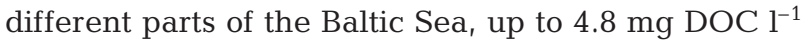
was observed, which is similar to the maximal $5.5 \mathrm{mg} \mathrm{C}$ $\mathrm{l}^{-1}$ we measured at the outer coastal stations (Table 4). These values are the result of the important freshwater influx by rivers transporting organic matter into the almost completely enclosed Baltic Sea (Zweifel et al. 1995; cf. Fig. 2 for salinities). The range of DOC:POC ratios of 1 to 2 in the Darß-Zingst bodden chain (cf. Fig. 2) is at the lower end of reported values for polluted or eu- to hypertrophic waters (Table 4). The origin of the high POC levels in the Darß-Zingst bodden, which lowers the DOC:POC ratios so drastically, is assumed to be mainly autochthonous (Schumann et al. 2001) and is produced mainly by phytoplankton (Meyercordt et al. 1999).

There were DIN concentrations of up to $290 \mu \mathrm{mol}^{-1}$ at the estuarine stations and in the river Oberwarnow (cf. Fig. 3), so that a N-limitation of phytoplankton growth can be excluded at least for these sites and sampling dates. Nevertheless, their average C:N ratio of 9.1 was not lower than the average of all stations (cf. Fig. 4). However, for samples with a C:N ratio above 8.3, a moderate N-limitation of phytoplankton growth is assumed (Hecky et al. 1993). C:N ratios of marine phytoplankton growing with sufficient nitrogen are far lower, ranging between 3.5 and 6.9 (Jørgensen et al. 1991). While C:N ratios of flagellates exhibit similar values (Eccleston-Parry \& Leadbeater 1995), bacteria can have C: $\mathrm{N}$ ratios as low as 1.2 (Kuipers et al. 2000), but on the other hand can reach 13 when they grow very slowly (Goldman \& Dennett 2000). However, the average $\mathrm{C}: \mathrm{N}$ ratio of the Darß-Zingst bodden samples (median $=9.8, \mathrm{n}=8$ ) was significantly higher than that of the freshwater samples (median $=7.1, \mathrm{n}=6, \mathrm{p}=$ 0.02). In the bodden, up to $90 \%$ of POC does not belong to the biomass of micro-organisms, but represents refractory material with obviously little nitrogen content. Moreover, substantial parts of POC are not protein or carbohydrates (Schumann et al. 2001). Although the C:N ratio is not extraordinarily high, most POM is not readily degradable and may persist in the system. The biochemical composition of POM and its accessibility to micro-organisms, e.g. large mucus envelopes, particle sizes, aggregation status, limit its degradation additionally to nitrogen concentrations. Therefore, C:N ratios are not sufficient to assess the remineralisation rate of organic matter or explain its limitation by a single element, such as nitrogen.
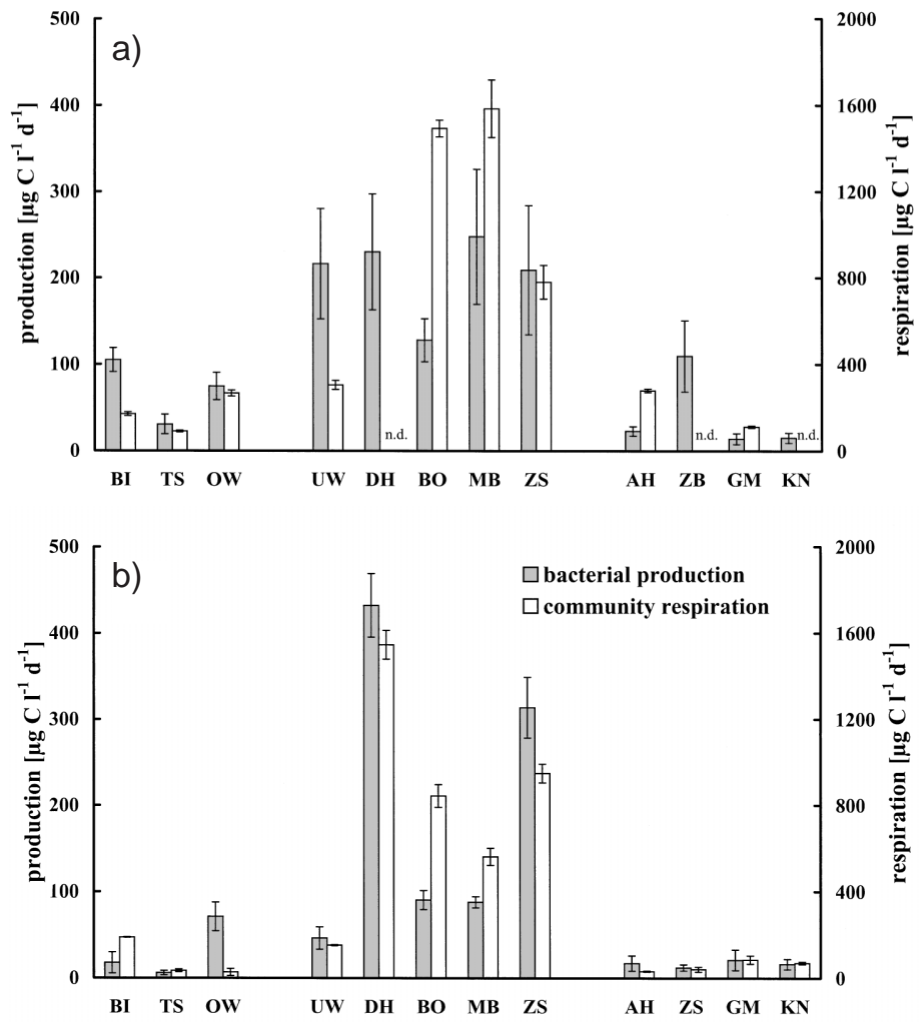

Fig. 6. Bacterial production calculated from ${ }^{3} \mathrm{H}$-thymidine uptake and community respiration $\left(\mu \mathrm{g} \mathrm{Cl}^{-1} \mathrm{~d}^{-1}\right)$ in (a) winter and (b) spring. Stations are arranged as in Fig. 2 (see Fig. 1 for station abbreviations). Error bars: SD of 5 replicate measurements for bacterial production and SE of the slope (linear regression of oxygen consumption over time). nd: not determined

The POC:chl a ratios of up to $23 \mathrm{~mol} \mathrm{C}(\mathrm{g} \mathrm{chl} \mathrm{a})^{-1}$ also seem to indicate nutrient-limited growth of phytoplankton in $3 / 4$ of all samples, if the indicator value of 4.2 to 8.3 for moderate and $>8.3$ for severe nutrient depletion is applied (Hecky et al. 1983). The POC:chl a ratios of the Darß-Zingst bodden samples were all $>11$, but not significantly different from the freshwater and marine sites (cf. Fig. 4). However, POC:chl a ratios of phytoplankton are strongly species specific, increase significantly with light (Falkowski et al. 1985) and decrease with nitrogen availability (e.g. Riemann et al. 1989) or under mixotrophic growth (Laliberté \& de la Noüe 1993). As there are so manifold influential factors on cellular chl a content, direct conclusions cannot be drawn from POC:chl a ratios. The high ratios, especially in the Darß-Zingst bodden, should better be interpreted as a small contribution of phytoplankton carbon to POM unless biovolumes are quantified and converted to carbon.

The high C:N ratio, the low chl a content along with the high percentages of non-carbohydrate and non- 

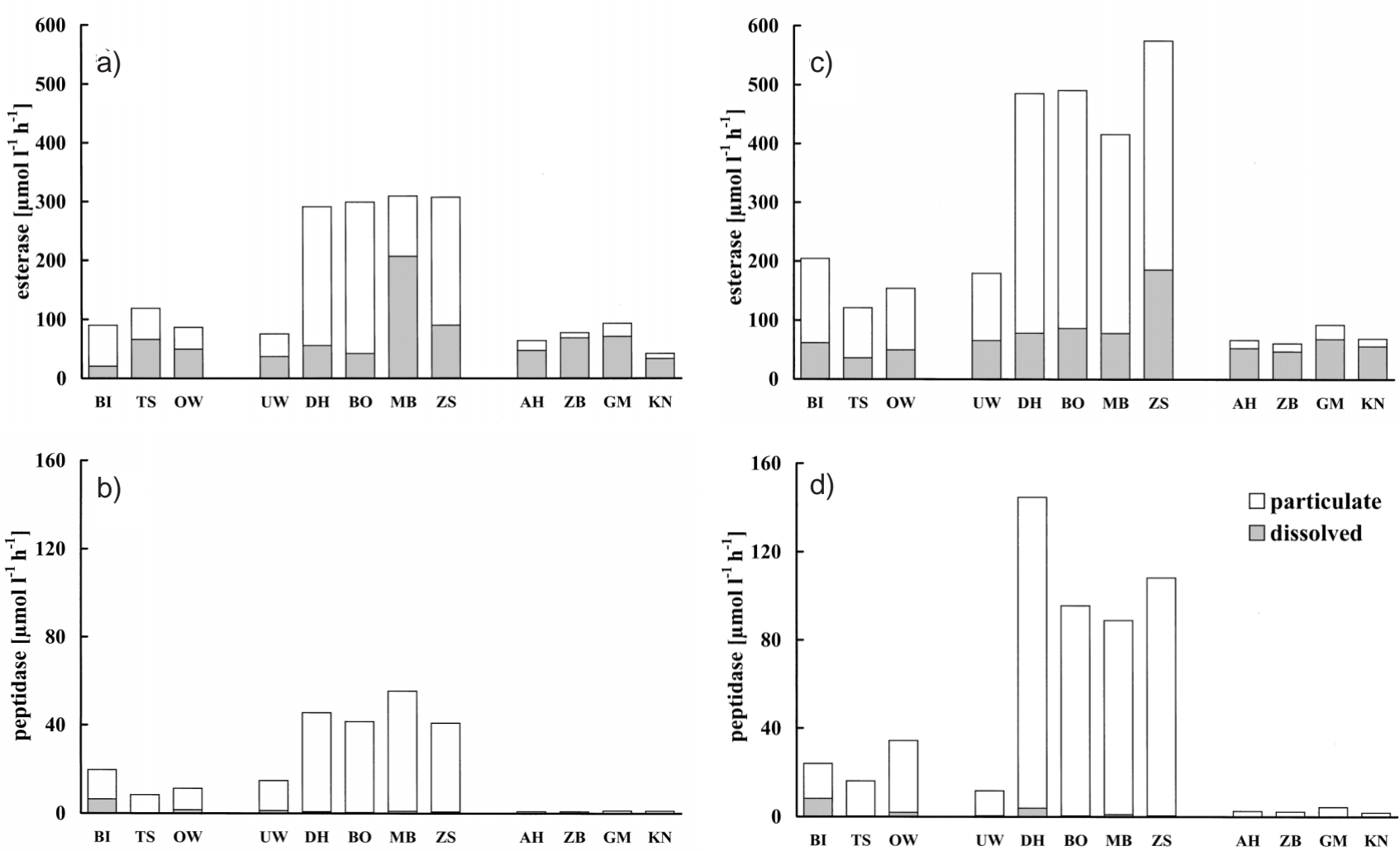

Fig. 7. (a) Particle-associated and free-dissolved esterase and (b) peptidase activity $\left(\mu \mathrm{mol} \mathrm{l}^{-1} \mathrm{~h}^{-1}\right.$ ) in winter and (c) esterase and (d) peptidase activity in spring. Stations are arranged as in Fig. 2 (see Fig. 1 for station abbreviations)

protein material (Schumann et al. 2001) in POM of the Darß-Zingst bodden chain indicate a high contribution of refractory material to POM. The small rivers and brooks entering the bodden chain carry only a small load of POM, but high amounts of DOM (unpubl. data). Additionally, only $10 \%$ of water influx is freshwater (Schlungbaum et al. 1994). Therefore, rivers cannot be an important source for the high POM values in the bodden. The low contribution of phytoplankton biomass to POM measured on a volume and carbon concentration basis (Schumann et al. 2001), which is also reflected by the high POC:chl $a$ ratios, leads to the conclusion that most of the POM is not 'new' material, but strongly degraded. This degradation takes place mostly in the sediments. Due to frequent wind-induced resuspension of the upper sediment particles, this decomposed material is mixed into the pelagial (Rieling 2000). The narrow connection to the Baltic Sea in the east (cf. Fig. 1) restricts the exchange with the Baltic Sea, so that the water exchange rates are about 6 - to 7 -fold $\mathrm{yr}^{-1}$ in the innermost Saaler Bodden at Stn DH and 55-fold in the Barther Bodden at Stn MB (Schlungbaum et al. 1994). The POM export from the bodden into the Baltic Sea must be small.

\section{Darß-Zingst bodden-high abundance of heterotrophic micro-organisms}

Bacterial abundance was highest in the hypertrophic Darß-Zingst bodden (cf. Fig. 5), but did not reach the extreme values of up to $46 \times 10^{6} \mathrm{ml}^{-1}$ reported for these systems in Klinkenberg \& Schumann (1995). Bacterial numbers in the limnetic samples of 4 to $11 \times 10^{6} \mathrm{ml}^{-1}$ are typical for many other freshwater systems of all trophic grades. There are several reports of higher bacterial cell numbers in the Baltic Sea than we quantified in our samples (cf. overview in Klinkenberg \& Schumann 1995). This may be due to the low water temperatures of up to $5.5^{\circ} \mathrm{C}$ even in the spring samples (cf. Table 1).

Heterotrophic ciliate abundance in the Darß-Zingst bodden chain was in the range of that reported for earlier years (Schumann \& Schiewer 1994). Since 1991/1992, ciliates have been dominated by small species $(<40 \mu \mathrm{m}$ diameter) of the orders Oligotrichida, Hymenostomatida and Cyclotrichida. Similar high abundances were only found in eu- and hypertrophic lakes (cf. overview in Foissner et al. 1999) or in the Rhode river estuary (Dolan \& Gallegos 1991), especially if minute or nanociliates prevailed as in the Darß- 
Zingst bodden. Such small ciliates are predominantly bacterivorous (Šimek et al. 1990, Sommaruga \& Psenner 1995).

The abundance of heterotrophic flagellates, most of them in the 'nano' size class, peaked at a comparably high value of $4700 \mathrm{ml}^{-1}$ in the Darß-Zingst bodden (cf. overview in Sanders et al. 1992), and exceeded that in several other estuaries (Dolan \& Gallegos 1991, Laybourn-Parry et al. 1992, El Serehy \& Sleigh 1993) and some lakes (Carlough \& Meyer 1991, Vörös et al. 1996).
Heterotrophic nanoflagellates were not so abundant at the limnetic stations and in the Baltic Sea (cf. Fig. 5) although they are the main grazers of bacterioplankton in most aquatic systems. The abundance of both bacteria and flagellates related mainly to the trophic status and not to salinity (Sanders et al. 1992). Since bacterial and flagellate abundances are positively correlated, if data of various systems are considered (Berninger et al. 1991), the supply of bacteria as flagellate food seems to control their growth from bottom-up. How-

Table 4. DOC concentrations ( $\mathrm{mg} \mathrm{C}^{-1}$ ) and DOC:POC ratios in marine, estuarine and limnetic waters

\begin{tabular}{|c|c|c|c|c|}
\hline & Characteristics & DOC & DOC:POC & Source \\
\hline \multicolumn{5}{|l|}{ Marine } \\
\hline Georges Bank & Continental shelf & $0.6-1.0$ & & Chen et al. (1996) \\
\hline Middle Atlantic Bight & & $0.6-1.1$ & & Guo et al. (1995) \\
\hline Arctic ice & & 1.3 & & Amon et al. (2001) \\
\hline Bedford Basin, Nova Scotia & Small coastal bay & $0.8-1.9$ & & Kepkay et al. (1993) \\
\hline Gulf of Mexico & & $0.5-2.6$ & & Guo et al. $(1994,1995)$ \\
\hline Baltic Sea (Bothnian Sea) & & $3.0-4.8$ & & Zweifel et al. (1995) \\
\hline Baltic Sea (Kattegat) & Coastal area & Averages: $2.4-4.3$ & & Middelboe \& Søndergaard (1995) \\
\hline Southern Baltic Sea & Mesotrophic coastal area & $3.7-5.5$ & $5-138$ & This study \\
\hline Southern Baltic Sea & & Averages: $5.7-5.9$ & & Ferrari et al. (1996) \\
\hline Alexandria Harbour & Highly polluted & & 2.5 & Abdel Moati et al. (1991) \\
\hline Gulf of Trieste (Adriatic Sea) & & $1-10$ & & Herndl \& Malacic (1987) \\
\hline \multicolumn{5}{|l|}{ Estuarine } \\
\hline Pawcatuck River Estuary & Polluted & Averages: $2-7$ & & Doering et al. (1994) \\
\hline Unterwarnow & Polluted & $7.6-9.8$ & $5-6$ & This study \\
\hline 2 Florida salt marshes & & $3.0-12.1$ & & Coffin et al. (1993) \\
\hline Darß-Zingst boddens & Eu- to hypertrophic & $9.1-13.3$ & $1-2$ & This study \\
\hline Massachusetts estuaries & & $2.4-14.4$ & & Peterson et al. (1994) \\
\hline Delaware Bay salt marsh & & $1.5-15.5$ & & Roman \& Daiber (1989) \\
\hline 5 Florida estuaries & & $4.3-29.6$ & & Coffin et al. (1993) \\
\hline \multicolumn{5}{|l|}{ Limnetic } \\
\hline Lago Maggiore & & Averages: $0.8-1.5$ & & Bertoni \& Callieri (1992) \\
\hline Lake Constance & Mesotrophic & $1.4-2.3$ & & Weiss \& Simon (1999) \\
\hline Lake Klintsjön & Oligotrophic clearwater & 3.1 & & Tranvik \& Jørgensen (1995) \\
\hline Paraná River & & $1.3-5.5$ & $4-18$ & Depetris \& Kempe (1993) \\
\hline River Öre & & Averages: $6.0-6.9$ & & Wikner et al. (1999) \\
\hline 20 lakes in southern Québec & & Averages: $2.7-7.5$ & & del Giorgio \& Peters (1994) \\
\hline Lake Kjelsåsputten & Small, humic & 7.5 & 4 & Hessen (1992) \\
\hline Esrum Sø & Mesotrophic & Averages: $5.1-8.3$ & & Middelboe \& Søndergaard (1995) \\
\hline Lake Skärshultsjön & Oligotrophic humic & 10.3 & & Tranvik \& Jørgensen (1995) \\
\hline Bastrup Sø & Eutrophic & Averages: $11.0-11.4$ & & Middelboe \& Søndergaard (1995) \\
\hline 3 freshwaters (NE Germany) & Meso- to eutrophic & $8.8-12.2$ & $8-22$ & This study \\
\hline Chillisquaque Creek system & Fed by a eutrophic pond & $4.9-13.7$ & & Ciaio \& McDiffett (1990) \\
\hline River Meuse & Polluted & ca. $3-14$ & $1-12$ & Descy \& Gosselain (1994) \\
\hline Frederiksborg Slotsø & Hypertrophic & Averages: $10.3-15.2$ & ca. $2-4$ & $\begin{array}{l}\text { Middelboe \& Søndergaard (1995), } \\
\text { Søndergaard et al. (1995) }\end{array}$ \\
\hline Grib Sø & Humic & Averages: $16.6-19.7$ & & Middelboe \& Søndergaard (1995) \\
\hline River Kiiminkijoki & Humic & $7.8-21.3$ & $3-22$ & Heikkinen (1989) \\
\hline River Krutynia & Lake-river system & $6.5-23.8$ & $>3$ & Radwan et al. (1992) \\
\hline Hartbeespoort Dam & Hypertrophic reservoir & $5.0-24.8$ & & Robarts et al. (1990) \\
\hline Lake Mekkojärvi & Acid, polyhumic & $8.0-25.0$ & & Münster et al. (1992) \\
\hline
\end{tabular}


ever, there is also evidence of a strong top-down control of the flagellate biomasses (Gasol et al. 1995). Nevertheless, heterotrophic nanoflagellates remove substantial parts of bacterial production (up to $21 \%$ bacteria $\mathrm{d}^{-1}$; Šimek et al. 1990). Moreover, they seem to graze especially on the active portion of bacterioplankton (del Giorgio et al. 1996). Therefore, data on nanoflagellates should always be included in the discussion of bacterial activity.

Although the abundances of heterotrophic nanoflagellates were high in the bodden, bacterial cell numbers were also high (cf. Fig. 5) and could have sustained many more flagellates (Berninger et al. 1991). The top-down control of the main bacterial grazers does not seem to be strong enough to reduce their cell numbers further. This could have been caused by a high grazing pressure on flagellates performed by ciliates. Abundances of almost 400 ind. $\mathrm{ml}^{-1}$ were observed earlier in the bodden (Schumann \& Schiewer 1994), but not during the investigation period in 2000 . Such high abundances of 200 ciliates $\mathrm{ml}^{-1}$ were found only occasionally in some hypertrophic lakes (Foissner et al. 1999). In contrast to the high protozoan biomasses in the bodden, at the Baltic Sea locations, nanoflagellates were often absent. Ciliate abundances were well in the range of mesotrophic lakes (Foissner et al. 1999). Nevertheless, bacterial abundance remained low, indicating a bottom-up limitation of bacteria, probably simply by temperature (cf. $T_{\mathrm{W}}$ in Table 1 and bacterial production in Fig. 6). However, since we could not estimate grazing rates of flagellates on bacteria, feeding modes and preferred food types of ciliates, we cannot prove that ciliates regulate flagellate development or if ciliates themselves feed substantially on bacteria. This open question also demonstrates the importance of thorough investigations on aquatic protozoa. Unfortunately, protozoa are not part of any European or national monitoring program, which include phytoplankton, macrozoo- and macrophytobenthos, and sometimes metazooplankton. Aquatic bacteria are investigated solely with respect to human pathogenity. Data on bacteria, protozoa and microbial turn-over of organic matter can therefore only be derived from basic research of universities or research institutions, which often cannot sustain longterm or large-scale research strategies.

\section{Darß-Zingst bodden-high microbial activities, but low bacterial productivity}

The freshwater and Baltic Sea samples had production rates higher than the average of freshwater or marine systems, respectively. However, from eutrophic and polluted freshwater sites there are occasional reports of higher maximal production rates (Chrzanowski \& Hubbard 1989, Hudson et al. 1992, Servais \& Garnier 1993). Although bacterial production in the Darß-Zingst bodden was enhanced compared to the other investigated systems (cf. Fig. 6), it was in the typical range for estuarine and coastal locations (cf. overview in White et al. 1991). Compared to the high standing stock of bacterioplankton in the bodden (Klinkenberg \& Schumann 1995), bacterial production is rather low, which is reflected by a low productivity of $0.6 \mathrm{~d}^{-1}\left(0.1\right.$ to $\left.0.8 \mathrm{~d}^{-1}\right)$. Bacterial productivity at the investigated freshwater and Baltic Sea stations was even lower ( 0.3 and $\left.0.5 \mathrm{~d}^{-1}\right)$.

Community respiration was low at the investigated freshwater stations (28 to $267 \mu \mathrm{g} \mathrm{C} \mathrm{l}^{-1} \mathrm{~h}^{-1}$ ) and at the

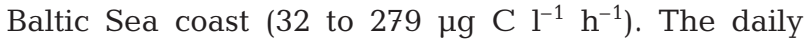
respiration in the Darß-Zingst bodden was in the range of eutrophic lakes (e.g. Schwaerter et al. 1988) and reached, at a maximum (up to $1585 \mu \mathrm{g} \mathrm{C}^{-1} \mathrm{~h}^{-1}$ ), values of a fertilised fish pond (Szyper et al. 1992). Because the contribution of bacteria to the community respiration was not investigated, we cannot conclude something about bacterial specific activity. The high protozoan abundance, especially in the bodden, suggests a high contribution of these heterotrophic organisms to the community respiration. The respiration of the high phytoplankton biomass in the bodden (Schumann et al. 2001) may substantially contribute to total community respiration in the dark, not only at night, but also due to a very low light penetration during the day (Sagert \& Schubert 1999).

The activity of leucine-aminopeptidase of 0.9 to $4 \mu \mathrm{mol} \mathrm{l^{-1 }} \mathrm{h}^{-1}$ measured in the Baltic Sea samples is very high compared to published values. Only in the Adriatic Sea were similar high values of 0.1 to $1.7 \mu \mathrm{mol} \mathrm{l} \mathrm{l}^{-1} \mathrm{~h}^{-1}$ found (Karner et al. 1992). Peptidase activities measured in the fresh and brackish water samples were at least 6-fold higher than those we found in the literature for highly eutrophic systems (e.g. Hoppe et al. 1998). These comparatively high values could be the result of some of the methodological conditions we chose. We used almost optimal $\mathrm{pH}$ and temperature conditions for aminopeptidases (cf. Chróst 1992). The linear increase of the fluorescent hydrolysis product was surveyed in every sample. The incubation time was adjusted accordingly. We dissolved the only slightly water-soluble fluorogenic substrates in a very strong organic solvent like Hoppe et al. (1988), which insures that all fluorogenic substrate molecules are available to the enzymes. On the other hand, most of the samples were taken from very shallow waters, where much resuspended material from the sediment surface can be found in the pelagic zone (cf. POC in Fig. 2). Therefore, particle-associated micro-organisms from the benthal and their enzymes were included in 
the measurements of the plankton samples, which may have contributed substantially to total enzyme activity. However, it remains unclear why we could not measure higher cell-specific bacterial production rates. One reason may be that the oxygen-saturated pelagic conditions suppress the growth rates of anaerobic and facultatively aerobic bacteria from the anoxic sediments if they are resuspended. The high free-dissolved esterase activity we measured in all pelagial samples (Fig. $7 \mathrm{a}, \mathrm{C}$ ) is, on a volume basis, well within the range measured for the upper $\mathrm{cm}$ of sediments in neighbouring coastal waters (Köster et al. 1997). This may be due to resuspension of material or even dissociation of enzyme molecules into the water column from the sediments. Unfortunately, quantitative data for esterase activities in different pelagic systems are very rare, because most researchers concentrate on peptidases, chitinases, glucosidases and phosphatases (e.g. Hoppe et al. 1998). All parameters of microbial activity measured in this study, increased significantly with POC, DOC and bacterial abundances (Tables 2 \& 3). Unlike the $\mathrm{P}: \mathrm{B}$ ratios of bacteria, the cell-specific enzyme activities were significantly correlated with bacterial cell numbers. This suggests that samples with high concentrations of organic matter and bacteria had not only more bacteria but more hydrolytically active bacteria. However, this interpretation of ratios and correlations holds true only if the assumption is made that bacteria are the sole or predominant source of hydrolytic enzyme activities in water samples, which may not be always the case (cf. Schumann et al. 2003).

Acknowledgements. This work was financially supported by the Graduiertenkolleg 'Integrative analysis of tideless shallow estuaries' promoted by the Deutsche Forschungsgemeinschaft and a doctoral fellowship by the Fazit foundation of the Gemeinnützige Verlagsgesellschaft to A.H. We thank Ulf Karsten for critical comments on an earlier version of the manuscript, and Sibylle Müller and Birgit Martin for their technical assistance with the chemical analyses.

\section{LITERATURE CITED}

Abdel Moati AR, Aboul Kassim TA, Dowidar NM, El Nady FE (1991) Carbon fractionation and balance in the Eastern Harbour of Alexandria, Egypt. J Coast Res 7:377-386

Amon RMW, Fitznar HP, Benner R (2001) Linkages among bioreactivity, chemical composition, and diagenetic state of marine dissolved organic matter. Limnol Oceanogr 46: 287-297

Bell RT (1993) Estimating production of heterotrophic bacterioplankton via incorporation of tritiated thymidine. In: Kemp PF, Sherr BF, Sherr EB, Cole JJ (eds) Handbook of methods in aquatic microbial ecology. Lewis Publishers, Boca Raton, FL, p 495-503

Berninger UG, Caron DA, Sanders RW, Finlay BJ (1991) Heterotrophic flagellates of planktonic communities, their characteristics and methods of study. In: Patterson DJ,
Larsen J (eds) The biology of free-living heterotrophic flagellates. Clarendon Press, Oxford, p 39-56

Bertoni R, Callieri C (1993) Organic carbon trend during the oligotrophication of Lago Maggiore. Mem Ist Ital Idrobiol 52:191-205

Carlough LA, Meyer JL (1991) Bacterivory by sestonic protists in a southeastern blackwater river. Limnol Oceanogr 36: 873-883

Chen RF, Fry B, Hopkinson CS, Repeta DJ, Peltzer ET (1996) Dissolved organic carbon on Georges Bank. Cont Shelf Res 16:409-420

Chróst RJ (1992) Significance of bacterial ectoenzymes in aquatic environments. Hydrobiologia 243/244:61-70

Chróst RJ, Wcislo R, Halemejko GZ (1986) Enzymatic decomposition of organic matter by bacteria in an eutrophic lake. Arch Hydrobiol 107:145-165

Chrzanowski TH, Hubbard JG (1989) Bacterial utilization of algal extracellular products in a southwestern reservoir. Hydrobiologia 179:61-71

Ciaio CJ, McDiffett WF (1990) Dissolved organic carbon dynamics in a small stream. J Freshw Ecol 5:383-390

Coffin RB, Connolly JP, Harris PS (1993) Availability of dissolved organic carbon to bacterioplankton examined by oxygen utilization. Mar Ecol Prog Ser 101:9-22

Dale T, Burkill PH (1982) Live counting - a quick and simple technique for enumerating pelagic ciliates. Ann Inst Oceanogr 58:267-276

del Giorgio PA, Peters RH (1994) Patterns in planktonic P:R ratios in lakes: Influence of lake trophy and dissolved organic carbon. Limnol Oceanogr 39:772-787

del Giorgio PA, Gasol JM, Vaque D, Mura P, Agusti S, Duarte CM (1996) Bacterioplankton community structure: protists control net production and the proportion of active bacteria in a coastal marine community. Limnol Oceanogr 41: 1169-1179

Depetris PJ, Kempe S (1993) Carbon dynamics and sources in the Parana River. Limnol Oceanogr 38:382-395

Descy JP, Gosselain V (1994) Development and ecological importance of phytoplankton in a large lowland river (River Meuse, Belgium). Hydrobiologia 289:139-155

Doering PH, Oviatt CA, McKenna JH, Reed LW (1994) Mixing behavior of dissolved organic carbon and its potential biological significance in the Pawcatuck River estuary. Estuaries 17:521-536

Dolan JR, Gallegos CL (1991) Trophic coupling of rotifers, microflagellates, and bacteria during fall months in the Rhode river estuary. Mar Ecol Prog Ser 77:147-156

Eccleston-Parry JD, Leadbeater BSC (1995) Regeneration of phosphorus and nitrogen by four species of heterotrophic nanoflagellates feeding on three nutritional states of a single bacterial strain. Appl Environ Microbiol 61:1033-1038

El Serehy HAH, Sleigh MA (1993) Ciliates in the plankton of the River Itchen estuary, England. Acta Protozool 32: 183-190

Falkowski PG, Dubinsky Z, Wyman K (1985) Growth-irradiance relationships in phytoplankton. Limnol Oceanogr 30: 311-321

Ferrari GM, Dowell MD, Grossi S, Targa C (1996) Relationship between the optical properties of chromophoric dissolved organic matter and total concentration of dissolved organic carbon in the southern Baltic Sea region. Mar Chem 55:299-316

Foissner W, Berger H, Schaumburg J (1999) Identification and ecology of limnetic plankton ciliates. Bayerisches Landesamt für Wasserwirtschaft, München

Fuhrman JA, Azam F (1982) Thymidine incorporation as a measure of heterotrophic bacterioplankton production in 
marine surface waters: evaluation and field results. Mar Biol 66:109-120

Gasol JM, Simons AM, Kalff J (1995) Patterns in the top-down versus bottom-up regulation of heterotrophic nanoflagellates in temperate lakes. J Plankton Res 17:1879-1903

Gewässergütebericht Mecklenburg-Vorpommern (1996/ 1997) Zustand der Gewässergüte von Fließ-, Stand- und Küstengewässern und der Grundwasserbeschaffenheit in Mecklenburg-Vorpommern. Umweltministerium, Mecklenburg-Vorpommern, Schwerin

Goldman JC, Dennett MR (2000) Growth of marine bacteria in batch and continuous culture under carbon and nitrogen limitation. Limnol Oceanogr 45:789-800

Guo L, Coleman CHJ, Santschi PH (1994) The distribution of colloidal and dissolved organic carbon in the Gulf of Mexico. Mar Chem 45:105-119

Guo L, Santschi PH, Warnken KW (1995) Dynamics of dissolved organic carbon (DOC) in oceanic environments. Limnol Oceanogr 40:1392-1403

Hecky RE, Campbell P, Hendzel LL (1993) The stoichiometry of carbon, nitrogen, and phosphorus in particulate matter of lakes and oceans. Limnol Oceanogr 38:709-724

Heikkinen K (1989) Organic carbon transport in an undisturbed boreal humic river in northern Finland. Arch Hydrobiol 117:1-19

Herndl GJ, Malacic V (1987) Impact of the pycnocline layer on bacterioplankton: diel and spatial variations in microbial parameters in the stratified water column of the Gulf of Trieste (Northern Adriatic Sea). Mar Ecol Prog Ser 38: 295-303

Hessen DO (1992) Dissolved organic carbon in a humic lake: effects on bacterial production and respiration. Hydrobiologia 229:115-123

Hoppe HG (1983) Significance of exoenzymatic activities in the ecology of brackish water: measurements by means of methylumbelliferyl-substrates. Mar Ecol Prog Ser 11: 299-308

Hoppe HG, Kim SJ, Gocke K (1988) Microbial decomposition in aquatic environments: combined process of extracellular enzyme activity and substrate uptake. Appl Environ Microbiol 54:784-790

Hoppe HG, Giesenhagen HC, Gocke K (1998) Changing patterns of bacterial substrate decomposition in a eutrophic gradient. Aquat Microb Ecol 15:1-13

Hubberten U (1994) Aminosäuren und Huminstoffe im Stickstoffkreislauf polarer Meere. Ber Polarforsch 153:123

Hübener T, Klinkenberg G, Börner R (1996) Enzymatische Aktivität des Bakterio- und Phytoplanktons der Warnow in den Jahren 1992-1993. Vom Wasser 87:409-416

Hudson JJ, Roff JC, Burnison BK (1992) Bacterial productivity in forested and open streams in southern Ontario. Can J Fish Aquat Sci 49:2412-2422

Jeffrey SW, Humphrey SF (1975) New spectrophotometric equations for determining chlorophylls a, b, c in higher plants, algae and natural phytoplankton. Biochem Physiol Pflanz 167:191-194

Jørgensen SE, Nielsen SN, Jørgensen LA (1991) Handbook of ecological parameters and ecotoxicology. Elsevier, Amsterdam, p 1263

Jürgens K, Arndt H, Zimmermann H (1997) Impact of metazoan and protozoan grazers on bacterial biomass distribution in microcosm experiments. Aquat Microb Ecol 12: $131-138$

Karner M, Fuks D, Herndl G (1992) Bacterial activity along a trophic gradient. Microb Ecol 24:243-257

Kepkay PE, Niven SEH, Milligan TG (1993) Low molecular weight and colloidal DOC production during a phyto- plankton bloom. Mar Ecol Prog Ser 100:233-244

Kirchman D, K'nees E, Hodson R (1985) Leucine incorporation and its potential as a measure of protein synthesis by bacteria in natural aquatic systems. Appl Environ Microbiol 49:599-607

Klinkenberg G, Schumann R (1995) Abundance changes of autotrophic and heterotrophic picoplankton in the Zingster Strom, a shallow, tideless estuary south of the DarßZingst Peninsula (Southern Baltic Sea). Arch Hydrobiol 134:359-377

Köster M, Dahlke S, Meyer-Reil LA (1997) Microbiological studies along a gradient of eutrophication in a shallow coastal inlet in the southern Baltic sea (Nordrügensche Bodden). Mar Ecol Prog Ser 152:27-39

Kuipers B, van Noort GJ, Vosjan J, Herndl GJ (2000) Diet periodicity of bacterioplankton in the euphotic zone of the subtropical Atlantic Ocean. Mar Ecol Prog Ser 201:13-25

Laliberté G, de la Noüe J (1993) Auto-, hetero-, and mixotrophic growth of Chlamydomonas humicola (Chlorophyceae) on acetate. J Phycol 29:612-620

Laybourn-Parry J, Rogerson A, Crawford DW (1992) Temporal patterns of protozooplankton abundance in the Clyde and Loch Striven. Estuar Coast Shelf Sci 35:533-543

Lindroth P, Mopper K (1979) High performance liquid chromatographic determination of subpicomole amounts of amino acids by precolumn fluorescence derivatisation with o-phthaldialdehyde. Anal Chem 51:1667-1674

Malcolm-Lawes DJ, Wong HW (1990) Determination of orthophosphate in water and soil using a flow analyzer. Analyst 15:65-67

Meyercordt J, Gerbersdorf S, Meyer-Reil LA (1999) Significance of pelagic and benthic primary production in two shallow coastal lagoons of different degrees of eutrophication in the southern Baltic Sea. Aquat Microb Ecol 20: 273-284

Middelboe M, Søndergaard M (1995) Concentration and bacterial utilization of submicron particles and dissolved organic carbon in lakes and a coastal area. Arch Hydrobiol 133:129-147

Münster U, Einiö P, Nurminen J, Overbeck J (1992) Extracellular enzymes in a polyhumic lake: Important regulators in detritus processing. Hydrobiologia 229:225-238

Peterson B, Fry B, Hullar M, Saupe S, Wright R (1994) The distribution and stable carbon isotopic composition of dissolved organic carbon in estuaries. Estuaries 17:111-121

Porter KG, Feig YS (1980) The use of DAPI for counting and identifying aquatic microflora. Limnol Oceanogr 25: 943-948

Radwan S, Kornijów R, Kowalczyk C (1992) Organic matter in the river Krutynia (Masurian Lakeland, Poland). Hydrobiologia 243/244:449-456

Rieling T, Gerbersdorf S, Stodian I, Black HJ, Dahlke S, Köster M, Meyercordt J, Meyer-Reil LA (2000) Benthic microbial decomposition of organic matter and nutrient fluxes at the sediment-water interface in a shallow coastal inlet of the southern Baltic Sea (Nordrügensche Bodden). In: Flemming BW, Delafontaine MT, Liebezeit G (eds) Muddy coast dynamics and resource management. Elsevier, Amsterdam, p 175-184

Riemann B, Bjørnsen PK, Newell S, Fallon R (1987) Calculation of cell production of coastal marine bacteria based on measured incorporation of $\left[{ }^{3} \mathrm{H}\right]$ thymidine. Limnol Oceanogr 32:471-476

Riemann B, Simonsen P, Stensgaard L (1989) The carbon and chlorophyll content of phytoplankton from various nutrient regimes. J Plankton Res 11:1037-1045

Robarts RD, Wicks RJ, Gehr R (1990) Seasonal changes in the 
dissolved free amino acid and DOC concentrations in a hypertrophic African reservoir and its inflowing rivers. Hydrobiologia 199:201-216

Robinson C, Archer SD, Williams PB (1999) Microbial dynamics in coastal waters of East Antarctica: plankton production and respiration. Mar Ecol Prog Ser 180:23-36

Rohde KH, Nehring D (1979) Ausgewählte Methoden zur Bestimmung von Inhaltsstoffen im Meer- und Brackwasser. Geod Geophys Veroeff 4:31-37

Roman CT, Daiber FC (1989) Organic carbon flux through a Delaware Bay salt marsh: tidal exchange, particle size distribution, and storms. Mar Ecol Prog Ser 54:149-156

Sagert S, Schubert H (1999) Unterwasserlichtklima der DarssZingster Boddenkette. Rostock Meeresbiol Beitr 7: 135-155

Sanders RW, Caron DA, Berninger UG (1992) Relationships between bacteria and heterotrophic nanoplankton in marine and fresh waters: an inter-ecosystem comparison. Mar Ecol Prog Ser 86:1-14

Schiewer U, Schumann R, Jost G, Sievert C (1991) Microbial food web dynamics in tideless eutrophic estuaries of the Baltic Sea. Kiel Meeresforsch Sonderh 8:20-28

Schlungbaum G, Selig U (1996) Die Warnow-ein typischer norddeutscher Flachlandfluß und seine Bedeutung für den Nährstoffeintrag in die Ostsee. Rostock Meeresbiol Beitr 4:67-84

Schlungbaum G, Baudler H, Nausch G (1994) Die Darß-Zingster Boddenkette-ein typisches Flachwasserästuar an der südlichen Ostseeküste. Rostock Meeresbiol Beitr 2: $5-26$

Schmidt I (1989) Investigations on the phytoplankton of the Unterwarnow in 1979/1980. Limnologica 20:165-182

Schumann R (1994) Zur Rolle des Pico-und Nanophytoplanktons im mikrobiellen Nahrungsgefüge der Darß-Zingster Boddenkette. PhD thesis, University of Rostock

Schumann R, Schiewer U (1994) Influence of abiotic induced phytoplankton changes on protozoan communities from the Darss-Zingst bodden chain (Germany). Mar Microb Food Webs 8:265-282

Schumann R, Sievert C, Schiewer U (1992) Structural compositions of pelagic communities in the River Warnow and their changes. Int Rev Ges Hydrobiol 77:173-185

Schumann R, Rentsch D, Görs S, Schiewer U (2001) Seston particles along a eutrophication gradient in coastal waters of the Southern Baltic Sea: significance of detritus and transparent mucoid material. Mar Ecol Prog Ser 218: $17-31$

Schumann R, Schiewer U, Karsten U, Rieling T (2003) Viability of bacteria from different aquatic habitats. II. Cellular fluorescent markers for membrane integrity and metabolic activity. Aquat Microb Ecol 32:137-150

Schwaerter S, Søndergaard M, Riemann B, Møller Jensen L (1988) Respiration in eutrophic lakes: the contribution of bacterioplankton and bacterial growth yield. J Plankton Res 10:515-531

Servais P, Garnier J (1993) Contribution of heterotrophic bacterial production to the carbon budget of the river Seine (France). Microb Ecol 25:19-33

Editorial responsibility: James Hollibaugh, Athens, Georgia, USA
Šimek K, Macek M, Seda J, Vyhnálek V (1990) Possible food chain relationships between bacterioplankton, protozoans, and cladocerans in a reservoir. Int Rev Ges Hydrobiol 75:583-596

Simon M, Azam F (1989) Protein content and protein synthesis of planktonic marine bacteria. Mar Ecol Prog Ser 51: 201-213

Sommaruga R, Psenner R (1995) Trophic interactions within the microbial food web in Piburger See (Austria). Arch Hydrobiol 3:257-278

Søndergaard M, Hansen B, Markager S (1995) Dynamics of dissolved organic carbon lability in a eutrophic lake. Limnol Oceanogr 40:46-54

Sugimura Y, Suzuki Y (1988) A high temperature catalytic oxidation method for the determination of non-volatile dissolved organic carbon in seawater by direct injection of a liquid sample. Mar Chem 24:105-131

Szyper JP, Rosenfeld JZ, Piedrahita RH, Giovannini P (1992) Diel cycles of planktonic respiration rates in briefly incubated water samples from a fertile earthen pond. Limnol Oceanogr 37:1193-1201

Tranvik LJ, Jørgensen NOG (1995) Colloidal and dissolved organic matter in lake water: carbohydrate and amino acid composition, and ability to support bacterial growth. Biogeochemistry 30:77-97

Verardo DJ, Froelich PN, McIntyre A (1990) Determination of organic carbon and nitrogen in marine sediments using the Carlo Erba NA-1500 Analyser. Deep-Sea Res Part I 37: $157-165$

Vörös L, V.-Balogh K, Herodek S (1996) Microbial food web in a large shallow lake (Lake Balaton, Hungary). Hydrobiologia 339:57-65

Wasmund N, Kell V (1991) Characterization of brackish coastal waters of different trophic levels by means of phytoplankton biomass and primary production. Int Rev Ges Hydrobiol 76:361-370

Wasmund N, Nausch G, Postel L, Witek Z and 12 others (2000) Trophic status of coastal and open areas of the south-eastern Baltic Sea based on nutrient and phytoplankton data from 1993-1997. Meereswiss Ber 38:83

Weiss M, Simon M (1999) Consumption of labile dissolved organic matter by limnetic bacterioplankton: the relative significance of amino acids and carbohydrates. Aquat Microb Ecol 17:1-12

White PA, Kalff J, Rasmussen JB, Gasol JM (1991) The effect of temperature and algal biomass on bacterial production and specific growth rate in freshwater and marine habitats. Microb Ecol 21:99-118

Wikner J, Cuadros R, Jansson M (1999) Differences in consumption of allochthonous DOC under limnic and estuarine conditions in a watershed. Aquat Microb Ecol 17: 289-299

Wilhelm SW, Smith REH (2000) Bacterial carbon production in Lake Erie is influenced by viruses and solar radiation. Can J Fish Aquat Sci 57:317-326

Zweifel UL, Wikner J, Hagström Å, Lundberg E, Norrman B (1995) Dynamics of dissolved organic carbon in a coastal ecosystem. Limnol Oceanogr 40:299-305

Submitted: March 22, 2002; Accepted: February 5, 2003

Proofs received from author(s): April 30, 2003 